595.79 T15b

I 



$$
\text { OAKST. HDSE }
$$





\section{BIOLOGICAL AND EMBRYOLOGICAL STUDIES \\ ON FORMICIDAE}

BY

MAURICE COLE TANQUARY

A. B., University of Illinois, 1907

A.M., University of Illinois, 1908

THESIS

Submitted in Partial Fulfilment of the Requirements for the

Degree of

DOCTOR OF PHILOSOPHY

IN ENTOMOLOGY

IN

THE GRADUATE SCHOOL

OF THE

UNIVERSITY OF ILLINOIS

1912 


\section{CONTENTS}

PAGE.

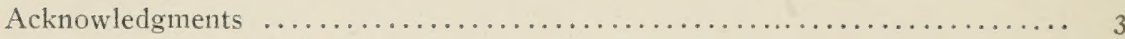



I. The life history of the corn-field ant, Lasius niger var. americanus Emery 5

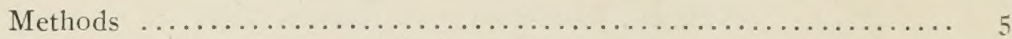

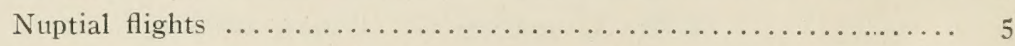

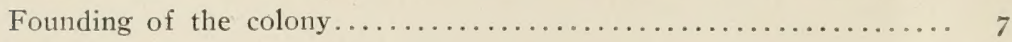

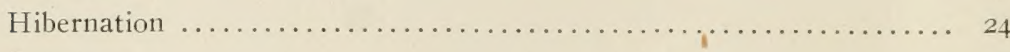

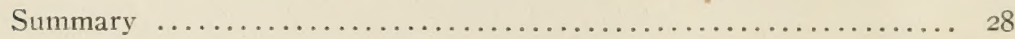



II. Experiments on the trail formation and orientation of the common house ant, Monomorium pharaonis L........................ $3 \mathrm{I}$

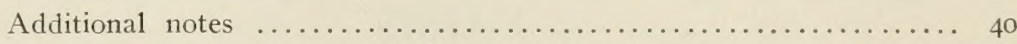

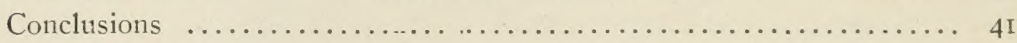

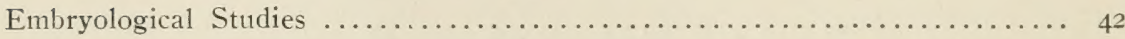

Studies on the embryology of Camponotus herculeanus var. ferrugineus Fabr. and Myrmica scabrinodis var. sabuleti Meinert.......... 42

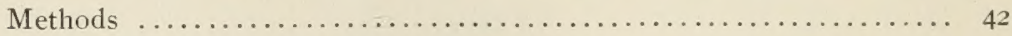



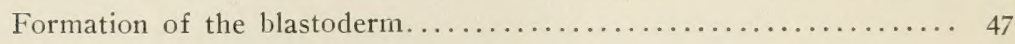

The development of the external form................... 56

The development of the external form of the embryo of Myrmica... 59

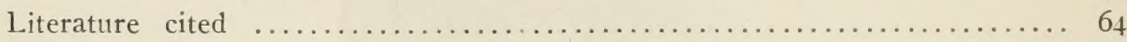

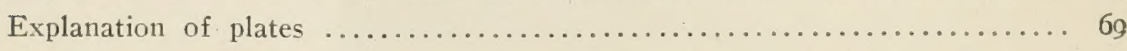

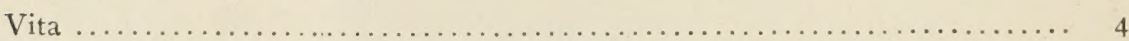






\section{ACKNOWLEDGMENTS}

The studies upon which this thesis is based have been prosecuted under the direction of Professor S. A. Forbes and Professor J. W. Folsom, the "Biological Studies" having been carried on under the direction of the former and the "Embryological Studies" under the direction of the latter. To both Professor Forbes and Professor Folsom, my sincerest thanks are due for their advice, encouragement, and assistance throughout the progress of the work. I wish also to acknowledge the aid of Mr. W. C. Matthews and Mr. Alvah Peterson in the preparation of the drawings. 


\section{VITA}

The writer was born at Lawrenceville, Illinois, November 26, I88I. He attended the public schools of Lawrenceville, and in I899 entered Vincennes University, from which he was graduated in I903. He taught for four years in the public schools of Lawrence county, Illinois. He entered the University of Illinois in 1905 , served for three semesters as undergraduate assistant in General Zoology, and was graduated in 1907. He then entered the Graduate School of the University of Illinois and received the degree of master of arts in Igo8. In 1908-1909 he was for half his time assistant to the State Entomologist of Illinois and a laboratory assistant in Vertebrate Embryology. From 1909 to 1912 he was half-time assistant in Entomology in the University of Illinois. During the summer of I9Io he studied in Harvard University, and during the summer of I9I I, he was Field Agent for the State Entomologist of Minnesota. He has published a paper in the April number of the Biological Bulletin for I9I I, on "Experiments on the Adoption of Lasius, Formica, and Polyergus Queens by Colonies of Alien Species," and one in the Transactions of the Illinois State Academy of Science for I9II, on "A preliminary List of the Ants of Illinois." 


\section{BIOLOGICAL STUDIES}

\section{The Life History of the Corn-Field Ant, Lasius niger var. americanus Emery}

Although the common corn-field ant, Lasius niger var. americamus Emery, is said to be the most abundant of all North American insects, its complete life history has never been worked out. The most that we have on the subject is given in Bulletin I3I of the Illinois Experiment Station by Forbes. He there reports that in four cases the first eggs from young queens were obtained May 8, 9, I0, and I 5 ; that the egg periods were $16,17,19$, and 23 days; that the pupal stage averaged about 18 days; and that the total number of young produced by a single female in the first year was in three cases 8, 9, and r9 workers. The more extensive data which I have been able to obtain correspond in great measure to those just given.

\section{METTHODS}

The method followed in this life history study consisted (I) in making observations in the field at all times of the year, (2) in making daily observations on young fertilized and isolated females through one season, (3) in isolating old queens from large nests and getting counts of the eggs they laid, and (4) in keeping large colonies in Fielde nests under daily observation. These young fertilized females were obtained in the fall just after they had descended from their nuptial flight, or after they had formed their cells; or they were taken from their cells in the spring before they had begun to lay eggs. They were kept for the most part in Fielde nests of the ordinary type, or in some cases in Barth nests. The latter are more satisfactory for keeping the ants under natural conditions, but with them one can not make as accurate observations regarding the exact number of eggs and young.

\section{NUP'TIAL FLIGHTS}

The nuptial flights of Lasius americanus usually occur from August to September. The date of a flight mentioned by Forbes is September I4. The earliest date for which I have positive evidence of a flight is September 5. I have noticed, however, in a summer's 
collecting, that during August the percentage of nests containing winged forms decreases, so that it is very probable that the flights begin during that month in this latitude. September 5, I9IO, I found a large number of young dealated females of Lasius niger americanus crawling on the ground in a park in Boston, Mass. This was about five o'clock in the evening. 'They had all removed their wings, and were crawling around in search of a place to burrow. A number were already beginning their burrows. At one place I saw six beginning to burrow in the same place. There were also many males flying in the air or crawling about, but I saw no couples in copula. The same afternoon I found five young dealated queens of $L$. latipes Walsh, a number of winged and dealated females of Solenopsis molesta Say, also a few dead males of Formica fusca var. subsericea Say. This fact indicates that weather conditions probably determine to a large extent the time of a flight. There had been a heavy rain the day before, but on that day it was clear and very warm. The following day, September 6, with the same weather conditions, I found a large number of males and winged females of Cremastogaster lineolata Say crawling about on the walks, and two days later I saw a large number of Solenopsis molesta flying, many of them in copula. September I9, I9IO, and on almost every day for the next ten days, I caught winged females of Lasius niger americamus flying or saw the young queens crawling over the ground. On the evening of October 4 , I found five winged and sixteen dealated queens of $L$. niger americamus crawling on the ground, one dealated queen October I I, and one October I8. The fact that dealated queens of this species are found crawling about is evidence that there has been a flight, since these queens begin to burrow immediately after descending from their flight and do not come to the surface again.

The dates upon which I have actually witnessed the flights of L. americanus from the nest are September 9, September 20, and September I8. All the flights of this species I have noticed have been between $3 \mathrm{p}$. $\mathrm{m}$. and $6 \mathrm{p}$. $\mathrm{m}$. The best observations were obtained from the one of September 20. In this case the entrance of a large nest was near the edge of a cement walk. At 4:30 p. m. my attention was called to the fact that a very large number of ants were crawling over the walk and grass near the opening. Closer examination showed that there were many males, winged females, and workers there, all running about excitedly, and that every few minutes a male or female rose from the blades of grass or the walk and flew away. They did not all fly away in the same direction, but seemed to take whatever 
course they were headed for. I did not see any pairs in copula either in the air or on the ground. In fact, I have never found a pair of this species in copula, and think it quite likely that fertilization takes place in the nest some time before the flight.

\section{FOUNDING OF THE COLONY}

Several methods of founding a colony are now generally recognized. These methods have been designated by Wheeler ('o6, pp. 34, 35 ) as the typical, the redundant, and the defective.

In the first case the female after descending from her nuptial flight, removes her wings and burrows into the ground or enters a cavity beneath the bark of a log, or the like, where she forms a small cell and begins to lay eggs or passes the winter and then begins to lay eggs. When these hatch she feeds the larvæ from her own secretions.

In the second case the female in addition to doing all that is required in the typical method, also cultivates certain fungi for herself and her brood.

The defective method Wheeler has subdivided into (I) temporary social parasitism, (2) permanent social parasitism, and (3) dulosis, or slavery. In temporary social parasitism the female enters a queenless colony of some other species and becomes adopted, thus getting the alien ants to rear her first brood. These alien ants naturally die off in the course of time, leaving a pure colony of the same species as the queen.

It is very well known that the first method mentioned is the one usually employed by L. niger americamus, and it is generally believed to be the only one employed. One may find solitary females in their cells a few inches beneath the surface of the ground in October and November; and may also find late in the summer or in the spring a colony consisting of a queen and a few minim workers and larvæ, the product of one year's growth.

November IS I found in a corn field infested with Aphis maidiradicis Forbes, six separate cells, each containing a solitary female. There were no eggs or young. The cells were only a few inches beneath the surface, three of them being beneath clods of earth. On April 5, I found a lone queen in her cell a few inches beneath the surface in a stalk-field, without eggs or young. Eggs may be laid, however, in the fall. On September 5, I picked up thirty-six dealated females that had just descended from their nuptial flights and placed them together in a large Fielde nest. Within the 
next few days between I 50 and 200 eggs were laid. These eggs, however, all spoiled, as though they were not properly taken care of. This has been the case in every other instance in which I have had young queens lay eggs in the fall. This, however, may be due to artificial conditions. The queens lay again in spring, about May, the exact time depending upon weather conditions. The one I collected April 5 and kept under natural conditions laid her first egg May I6. Some of the queens which I kept in a warm room during the winter began to lay as early as the first of March. The number of young produced the first season is very small as compared with the number of eggs laid by the queen. In all my nests containing single queens, the queen was more or less given to eating her own eggs. Some ate only a few, while others ate nearly all. This was not due to lack of food, as I had provided food for them. The fact that all the queens ate their eggs to some extent, and the fact that the number of young produced under natural conditions is so much less than the number of eggs laid, lead me to believe that the queen under normal conditions eats a certain proportion of her eggs. Possibly this habit enables her to get the proper kind of food for her larvæ.

The detailed history of a few first-year colonies follows.

\section{COLONY $27 b$}

This queen was taken November 20 , from a cell which she had established a few inches beneath the surface of the ground in a corn field. The room in which she was kept during the winter was a greenhouse, which became quite warm $\left(70^{\circ}-80^{\circ} \mathrm{F}\right.$. ) at times; though at other times the temperature fell below freezing. Keeping her in a warm room accounts for the fact that she began laying so early. Aside from the fact that egg-laying began much earlier, the history of this colony is not different from that of others in which the queens were kept under natural conditions, so that these results may be taken as typical.

The first egg was laid February I7. It disappeared February 22 (probably eaten) and no other was laid until February 27. 
Colony $276^{*}$

\begin{tabular}{|c|c|c|c|c|c|c|c|c|c|}
\hline \multicolumn{2}{|c|}{ Date } & \multirow{2}{*}{$\frac{\text { Eggs }}{1}$} & \multirow{2}{*}{$\frac{\text { Total }}{1}$} & \multirow[t]{2}{*}{ Larvæ } & Total & Рирæ & Total & Adults & Total \\
\hline Feb. & $27 \ldots$ & & & & & & & & \\
\hline & $28 \ldots$ & 1 & 2 & & & & & & \\
\hline Mar. & $4 \ldots$ & 1 & 3 & & & & & & \\
\hline “ & $5 . \ldots$ & 3 & 6 & & & & & & \\
\hline " & $6 \ldots$ & 1 & 7 & & & & & & \\
\hline “ & $8 \ldots$ & 2 & 9 & & & & & & \\
\hline “ & $10 \ldots$ & 2 & 11 & & & & & & \\
\hline “ & $11 \ldots$ & 3 & 14 & & & & & & \\
\hline “ & $12 \ldots$ & 1 & 15 & & & & & & \\
\hline “ & $16 \ldots$ & 2 & 17 & & & & & & \\
\hline “" & $17 . .$. & 4 & 21 & & & & & & \\
\hline$“$ & $18 \ldots$ & 1 & 22 & & & & & & \\
\hline “ & $21 \ldots$ & 2 & 24 & & & & & & \\
\hline " & $24 \ldots$ & 1 & 25 & & & & & & \\
\hline “ & $28 \ldots$ & 1 & 26 & & & & & & \\
\hline “ & $29 \ldots$ & 2 & 28 & & & & & & \\
\hline “ & $30 \ldots$ & 2 & 30 & & & & & & \\
\hline Apr. & $1 . .$. & 2 & 32 & & & & & & \\
\hline “ & $3 . .$. & 1 & 33 & & & & & & \\
\hline “ & $5 \ldots$ & 1 & 34 & & & & & & \\
\hline “" & $6 \ldots$ & 6 & 40 & & & & & & \\
\hline “ & $8 \ldots$ & 2 & 42 & & & & & & \\
\hline " & $12 \ldots$ & 4 & 46 & & & & & & \\
\hline$"$ & $13 \ldots$ & $1^{*}$ & 45 & & & & & & \\
\hline “ & $14 \ldots$ & 3 & 48 & & & & & & \\
\hline “" & $15 \ldots$ & 0 & 47 & 1 & 1 & & & & \\
\hline$"$ & $16 \ldots$ & 2 & 48 & 1 & 2 & & & & \\
\hline “" & $17 \ldots$ & 5 & 47 & 6 & 8 & & & & \\
\hline “ & $18 \ldots$ & $3 *$ & 41 & 3 & 11 & & & & \\
\hline “ & $19 \ldots$ & $1^{*}$ & 32 & 8 & 19 & & & & \\
\hline$"$ & $22 \ldots$ & 0 & 29 & 3 & 22 & & & & \\
\hline " & $23 \ldots$ & 2 & 30 & 1 & 23 & & & & \\
\hline “ & $24 \ldots$ & $5^{*}$ & 21 & 4 & 27 & & & & \\
\hline$"$ & $25 \ldots$ & 7 & 28 & 0 & 27 & & & & \\
\hline “ & $26 \ldots$ & 2 & 30 & 0 & 27 & & & & \\
\hline " & $27 \ldots$ & $6^{*}$ & 24 & 0 & 27 & & & & \\
\hline “ & $28 \ldots$ & 1 & 25 & $1^{*}$ & 26 & & & & \\
\hline " & $29 \ldots$ & $5^{*}$ & 20 & $5^{*}$ & 21 & & & & \\
\hline$"$ & $30 \ldots$ & $4^{*}$ & 16 & 0 & 21 & & & & \\
\hline
\end{tabular}

*In this table the asterisk signifies missing; the dagger, accidentally injured or destroyed; and the double dagger, dead. 
Colony 2zb-Continued

\begin{tabular}{|c|c|c|c|c|c|c|c|c|c|}
\hline \multicolumn{2}{|c|}{ Date } & \multirow{2}{*}{$\frac{\text { Eggs }}{0}$} & \multirow{2}{*}{$\frac{\text { Total }}{14}$} & \multirow{2}{*}{$\frac{\text { Larve }}{2}$} & \multirow{2}{*}{$\frac{\text { Total }}{22}$} & \multirow{2}{*}{$\frac{\text { Pupe }}{1}$} & \multirow{2}{*}{$\frac{\text { Total }}{1}$} & \multirow[t]{2}{*}{ Adlults : } & \multirow[t]{2}{*}{ Total } \\
\hline Miṣ. & 1.. & & & & & & & & \\
\hline$"$. & 3. & $3^{*}$ & 11 & 0 & 22 & 0 & 1 & & \\
\hline " & $4 \ldots$ & 0 & 11 & 0 & $: 22$ & 0 & 1 & & \\
\hline ". & 5. & 3 & 14 & $3^{*}$ & 18 & 1 & 2 & & \\
\hline " & $6 .$. & 0 & 9 & 5 & 22 & 1 & 3 & & \\
\hline “" & $\pi$ & $1^{*}$ & 7 & 1 & 22 & 1 & 4 & & \\
\hline “. & s... & 0 & 7 & $1^{*}$ & 20 & 1 & 5 & & \\
\hline “" & 9. & 1 & 8 & 0 & 19 & 1 & 6 & & \\
\hline ". & $10 \ldots$ & 2 & 9 & 1 & 17 & 3 & 9 & & \\
\hline “ & $11 \ldots$ & 1 & 8 & 2 & 19 & 0 & 9 & & \\
\hline “" & 12. & 1 & 9 & 0 & 18 & 1 & 10 & & \\
\hline “" & $13 .$. & 6 & 15 & 0 & 18 & 0 & 10 & & \\
\hline ". & $14 \ldots$ & 0 & 15 & 0 & 18 & 0 & 10 & & \\
\hline " & $16 \ldots$ & 4 & 19 & 0 & 18 & 0 & 10 & & \\
\hline “. & $17 .$. & 3 & 22 & 0 & 18 & 0 & 10 & & \\
\hline “ & $18 \ldots$ & $5^{*}$ & 17 & 0 & 18 & 0 & 10 & & \\
\hline “ & $19 .$. & $1^{*}$ & 16 & 0 & 18 & 0 & 10 & & \\
\hline ." & $20 \ldots$ & 0 & 16 & 0 & 17 & 1 & 11 & & \\
\hline “" & $21 \ldots$ & $1^{*}$ & 15 & $1^{*}$ & 15 & 1 & 12 & & \\
\hline " & $22 \ldots$ & 1 & 15 & 1 & 16 & 0 & 12 & & \\
\hline “ & 23. & 2 & 16 & 1 & 16 & 1 & 12 & 1 & 1 \\
\hline “ & $24 \ldots$ & $2^{*}$ & 14 & 0 & 16 & 0 & 12 & 0 & 1 \\
\hline " & $25 . \ldots$ & 1 & 15 & 0 & 16 & 0 & 12 & 0 & 1 \\
\hline " & $26 \ldots$ & 1 & 16 & $1^{*}$ & 15 & 0 & 12 & 0 & 1 \\
\hline “ & $2 \pi \ldots$ & 3 & 19 & 0 & 15 & 0 & 12 & 0 & 1 \\
\hline " & $28 \ldots$ & 4 & 22 & 1 & 14 & 2 & 13 & 1 & 2 \\
\hline “ & 29. & 10 & 32 & $4^{*}$ & 10 & 0 & 12 & 1 & 3 \\
\hline “ & $30 \ldots$ & $4^{*}$ & 28 & 0 & 10 & 0 & 11 & 1 & 4 \\
\hline " & $31 \ldots$ & $2^{*}$ & 26 & 0 & 10 & 0 & 11 & 0 & 4 \\
\hline June & $1 \ldots$ & 0 & 26 & 0 & 10 & 0 & 10 & 1 & 5 \\
\hline " & $2 \ldots$ & 4 & 30 & $2^{*}$ & 8 & $1^{*}$ & 8 & 1. & 6 \\
\hline " & $4 \ldots$ & 6 & 34 & 2 & 10 & $1^{*}$ & 5 & 2 & 8 \\
\hline “ & $5 \ldots$ & 0 & 33 & 1 & 11 & 0 & 4 & 1 & 9 \\
\hline ". & $6 \ldots$ & 3 & 36 & 0 & 11 & 0 & 4 & 0 & 9 \\
\hline “ & $7 \ldots$ & 0 & 36 & $2^{*}$ & 9 & 0 & 4 & $1^{\dagger}$ & 8 \\
\hline " & 8. & 0 & 36 & 0 & 9 & 0 & 4 & $1 t$ & 7 \\
\hline ". & 9 & $6^{*}$ & 30 & $2^{*}$ & 7 & 0 & 4 & 0 & 7 \\
\hline “ & $10 .$. & 5 & 35 & $1^{*}$ & 6 & 0 & 4 & 0 & 7 \\
\hline " & $11 \ldots$ & 12 & 46 & 1 & 6 & 1 & 5 & 0 & 7 \\
\hline " & $12 \ldots$ & $4^{*}$ & 42 & 0 & 4 & 2 & 7 & 0 & 7 \\
\hline “ & 13. & 3 & 42 & 3 & 6 & 1 & 8 & 0 & i \\
\hline
\end{tabular}


CoLony 28b-Continued

\begin{tabular}{|c|c|c|c|c|c|c|c|c|c|}
\hline & Date & Eggs & Total & Larve & Total & Рupæ & Total & Adults & Total \\
\hline June & $18 \S \ldots$ & 14 & 56 & $1^{*}$ & 2 & 3 & 9 & 2 & 9 \\
\hline & $19 \ldots$ & 5 & 61 & 0 & 2 & 0 & 8 & 1 & 10 \\
\hline$"$ & $20 \ldots$ & 0 & 59 & 2 & 4 & 0 & 8 & 0 & 10 \\
\hline$"$ & $21 \ldots$ & 5 & 63 & 1 & 5 & 0 & 8 & 0 & 10 \\
\hline$"$ & $23 \ldots$ & 4 & 64 & 3 & 8 & 0 & 8 & 0 & 10 \\
\hline$"$ & $24 \ldots$ & $8 *$ & 52 & 4 & 12 & 0 & 8 & 0 & 10 \\
\hline$"$ & $25 \ldots$ & 2 & 54 & 0 & 12 & 0 & 8 & 0 & 10 \\
\hline$"$ & $26 \ldots$ & 2 & 56 & $2^{*}$ & 9 & 1 & 9 & 0 & 10 \\
\hline$"$ & $27 \ldots$ & $\gamma^{*}$ & 46 & 3 & 12 & 0 & 9 & 0 & 10 \\
\hline$"$ & $28 \ldots$ & 3 & 47 & 2 & 14 & 0 & 9 & 0 & 10 \\
\hline$"$ & $29 \ldots$ & 0 & 47 & 0 & 14 & 0 & 7 & 2 & 12 \\
\hline$" “$ & $30 \ldots$ & $14^{*}$ & 30 & 3 & 17 & 0 & 5 & 2 & 14 \\
\hline July & $2 \ldots$ & $10^{*}$ & 20 & 0 & 17 & $1^{*}$ & 4 & 0 & 14 \\
\hline “ & $4 \ldots$ & 0 & 19 & 1 & 18 & 0 & 2 & 2 & 16 \\
\hline " & $5 \ldots$ & $4^{*}$ & 15 & 0 & 18 & 0 & 2 & 0 & 16 \\
\hline “ & $6 \ldots$ & 0 & 14 & 1 & 18 & 1 & 3 & 0 & 16 \\
\hline " & $7 \ldots$ & 0 & 13 & 1 & 18 & 1 & 4 & 0 & 16 \\
\hline “ & $8 \ldots$ & 0 & $1 ?$ & 0 & 18 & 0 & 3 & 1 & 17 \\
\hline$"$ & $9 \ldots$ & 0 & 10 & 3 & 21 & 0 & 3 & 0 & 17 \\
\hline “ & $10 \ldots$ & 2 & 12 & 0 & 20 & 1 & 4 & 0 & 17 \\
\hline$"$ & $11 \ldots$ & 2 & 14 & 0 & 20 & 0 & 4 & $1 \ddagger$ & 16 \\
\hline$"$ & $12 \ldots$ & 0 & 14 & 0 & 20 & 0 & 4 & 0 & 16 \\
\hline$"$ & $13 \ldots$ & 0 & 14 & $4 *$ & 16 & 0 & 4 & 0 & 16 \\
\hline " & $14 \ldots$ & 3 & 17 & 0 & 16 & 0 & 4 & 0 & 16 \\
\hline$"$ & $15 \ldots$ & 0 & 17 & 0 & 16 & 0 & 4 & 0 & 16 \\
\hline$"$ & $16 \ldots$ & 1 & 18 & $7 *$ & 9 & 0 & 3 & 1 & 17 \\
\hline$"$ & $17 \ldots$ & 4 & 22 & 0 & 9 & 0 & 3 & 0 & 17 \\
\hline$"$ & $18 \ldots$ & 0 & 22 & 0 & 9 & 0 & 3 & 0 & 17 \\
\hline “ & $19 \ldots$ & $s$ & 30 & 0 & 8 & 1 & 4 & 0 & 17 \\
\hline$"$ & $20 \ldots$ & 0 & 30 & 0 & 8 & 0 & 4 & 0 & 17 \\
\hline$"$ & $21 \ldots$ & 0 & 30 & 0 & 8 & 0 & 4 & 0 & 17 \\
\hline “ & $22 \ldots$ & s & 38 & $4^{*}$ & 3 & 1 & 5 & 0 & 17 \\
\hline “ & $23 \ldots$ & 0 & 38 & 0 & 3 & 0 & 5 & 0 & 17 \\
\hline$"$ & $24 \ldots$ & 0 & $3 s$ & 0 & 3 & 0 & 5 & 0 & 17 \\
\hline$"$ & $25 \ldots$ & 2 & 40 & 0 & 3 & 0 & 5 & 0 & 17 \\
\hline$"$ & $26 \ldots$ & 0 & 40 & 0 & 3 & 0 & 3 & 2 & 19 \\
\hline “ & $27 \ldots$ & 0 & 40 & 0 & 3 & 0 & 3 & 0 & 19 \\
\hline$" 6$ & $28 .$. & 0 & 40 & 0 & 3 & 0 & 3 & 0 & 19 \\
\hline$"$ & $29 \ldots$ & 0 & 39 & 1 & 3 & 1 & 3 & 1 & 20 \\
\hline " & $: 30 \ldots$ & 0 & 39 & 0 & 3 & 0 & 3 & 0 & 20 \\
\hline$"$ & $31 \ldots$ & 0 & 35 & 1 & 4 & 0 & 3 & 0 & 20 \\
\hline
\end{tabular}

\$une 14-17, no examination made. 
Colony $27 b$-Concluded

\begin{tabular}{|c|c|c|c|c|c|c|c|c|c|}
\hline \multicolumn{2}{|c|}{ Date } & \multirow{2}{*}{$\frac{\text { Eggs }}{0}$} & \multirow{2}{*}{$\frac{\text { Total }}{38}$} & \multirow{2}{*}{$\frac{\text { Larvæ }}{0}$} & \multirow{2}{*}{$\frac{\text { Total }}{4}$} & \multirow{2}{*}{$\begin{array}{c}\text { Pupæ } \\
0\end{array}$} & \multirow{2}{*}{$\frac{\text { Total }}{3}$} & \multirow{2}{*}{$\frac{\text { Adults }}{0}$} & \multirow{2}{*}{$\begin{array}{c}\text { Total } \\
20\end{array}$} \\
\hline Aug. & $1 .$. & & & & & & & & \\
\hline “ & $3 \ldots$ & 0 & 38 & 0 & 3 & 1 & 4 & 0 & 20 \\
\hline “ & $4 \ldots$ & 0 & 38 & 0 & 3 & 0 & 3 & 1 & 21 \\
\hline " & $5 \ldots$ & 0 & 38 & 0 & 2 & 1 & 4 & 0 & 21 \\
\hline " & 6. & 0 & 38 & 0 & 2 & 0 & 4 & 0 & 21 \\
\hline “ & $7 .$. & 0 & 38 & 0 & 2 & 0 & 4 & 0 & 21 \\
\hline “ & 8. & 0 & 38 & 0 & 2 & 0 & 3 & 1 & 22 \\
\hline “ & $9 .$. & 0 & 38 & 0 & 2 & 0 & 3 & 0 & 22 \\
\hline “ & $10 \ldots$ & $8^{*}$ & 30 & 0 & 2 & 0 & 3 & 0 & 22 \\
\hline$"$ & 11.. & 0 & 30 & 0 & 2 & 0 & 3 & 0 & 22 \\
\hline " & 12. & 1 & 31 & 0 & 2 & 0 & 3 & 0 & 22 \\
\hline “ & $14 \ldots$ & $3 *$ & 28 & $1^{*}$ & 1 & 0 & 2 & 1 & 23 \\
\hline " & $15 \ldots$ & 0 & 28 & 0 & 1 & 0 & 2 & 0 & 23 \\
\hline “ & 16. & 0 & 28 & 0 & 1 & $1^{*}$ & 1 & 0 & 23 \\
\hline " & $17 \ldots$ & 0 & 28 & 0 & 1 & 0 & 1 & 0 & 23 \\
\hline$"$ & 18. & 2 & 30 & 0 & 1 & 0 & 1 & 0 & 23 \\
\hline “ & 19. & 0 & 30 & 0 & 1 & 0 & 1 & 0 & 23 \\
\hline " & 23. & 0 & 30 & 0 & 1 & 0 & 0 & 1 & 24 \\
\hline$"$ & 25. & 9 & 38 & 1 & 2 & 0 & 0 & 0 & 24 \\
\hline Sept. & $1 .$. & 0 & 38 & 0 & 2 & 0 & 0 & 0 & 24 \\
\hline
\end{tabular}

I was compelled to neglect the colony for a time. September 25 , the nest contained 16 workers and 12 larvæ (the latter in poor condition); September 28, 5 eggs and I6 workers; and October 5, 2 larvæ and I 6 workers.

This colony, consisting of the queen, 2 larvæ, and I 6 workers, remained the same up to November I7, when I found one of the workers dead. By November i 6 the weather had become much colder, and during the rest of the winter the ants remained in a dormant condition. Owing to the fact that conditions were not just right, or that the ants were not in the best physiological condition to enter hibernation, the latter did not survive the winter.

An examination of the above data shows that up to September I, this queen had laid 222 eggs; that but 27 adults were reared from them; that but 3 adults died, one because I had injured it; that 4 individuals died or disappeared in the pupal stage, 42 in the larval stage, and $\mathrm{iog}$ in the egg stage. Whatever may have been the cause of the dying of the larvæ and pupæ, I am sure that at least a large percentage of the eggs was eaten, because many times I found eggs in the nest that had been partly eaten. 
Assuming that the first larvæ hatched from the first eggs, we have the following egg periods for the first 27 larva:

\begin{tabular}{|c|c|c|}
\hline & firs & \\
\hline & " next & (1) \\
\hline & “ & (1), 44 \\
\hline & “ & (3), 43 \\
\hline & $"$ & $(1), 42$ \\
\hline & “ & $(1), 40$ \\
\hline & $"$ & (1), 41 \\
\hline & " & ธצ \\
\hline & “ &  \\
\hline
\end{tabular}



On the same basis we find that the length of the larval stages for the first i 5 larva are as follows:

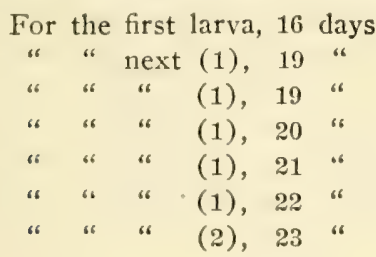

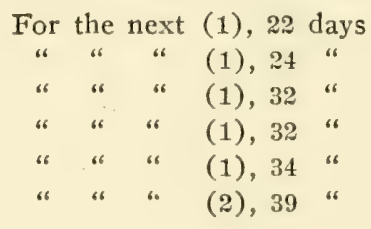

For the next few that transformed the time was still longer, but could not be determined exactly since some of the larvæ disappeared.

The pupal stages for the first I 5 adults are as follows:

\begin{tabular}{|c|c|c|c|c|}
\hline & the & first & 1 & \\
\hline & & next & $(3), 23$ & \\
\hline “ & " & & (2), 24 & \\
\hline & “" & & (1), 25 & \\
\hline & $"$ & & $(1), 26$ & \\
\hline & “ & “ & (1), 37 & \\
\hline
\end{tabular}

\begin{tabular}{|c|c|c|c|}
\hline F & the & nex & (1), 29 \\
\hline & s & as & $(2), 29$ \\
\hline & " & " & $(1), 37$ \\
\hline 4 & " & " & (1), 32 \\
\hline 4 & 6 & " & (1), 33 \\
\hline
\end{tabular}

Colony 27a*

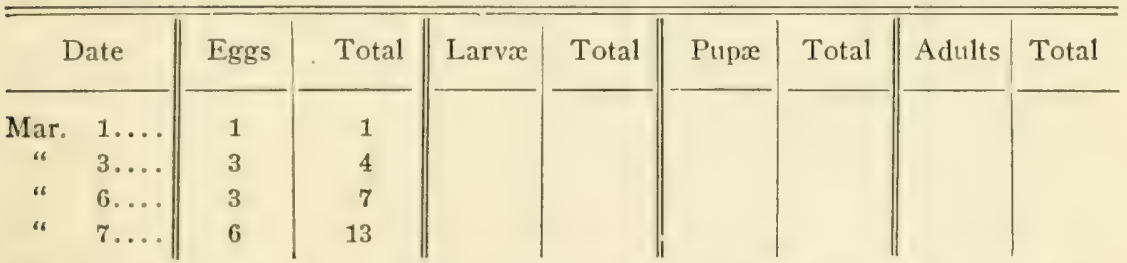

*In this table the asterisk signifies missing; and the dagger, accidentally injured or destroyed. 
Colony 2ra-Continued

\begin{tabular}{|c|c|c|c|c|c|c|c|c|c|}
\hline & Date & Eggs & Total & Larvæ & Total & Рирæ & Total & Adults & Total \\
\hline Mar. & $10 \ldots$ & 5 & 18 & & & & & & \\
\hline “ & $12 \ldots$ & 2 & 20 & & & & & & \\
\hline “" & $14 \ldots$ & $5^{*}$ & 15 & & & & & & \\
\hline “ & $16 \ldots$ & 4 & 19 & & & & & & \\
\hline " & $21 \ldots$ & 3 & 22 & & & & & & \\
\hline “ & $23 \ldots$ & 3 & 25 & & & & & & \\
\hline " & $24 \ldots$ & 2 & 27 & & & & & & \\
\hline " & $25 \ldots$ & 1 & 28 & & & & & & \\
\hline “" & $26 \ldots$ & 4 & 32 & & & & & & \\
\hline " & $28 \ldots$ & 3 & 35 & & & & & & \\
\hline$"$ & $29 \ldots$ & 4 & 39 & & & & & & \\
\hline Apr. & $1 \ldots$ & 1 & 40 & & & & & & \\
\hline " & $5 \ldots$ & 2 & 42 & & & & & & \\
\hline “ & $6 \ldots$ & $5 \dagger$ & 47 & & & & & & \\
\hline " & $6 \ldots$ & $5^{*}$ & 42 & & & & & & \\
\hline " & $7 \ldots$ & $6^{*}$ & 36 & & & & & & \\
\hline “ & $8 \ldots$ & 6 & 42 & & & & & & \\
\hline “ & $9 \ldots$ & 6 & 48 & & & & & & \\
\hline “ & $10 \ldots$ & 5 & 53 & & & & & & \\
\hline " & $11 \ldots$ & $3^{*}$ & 50 & & & & & & \\
\hline " & $12 \ldots$ & 11 & 61 & & & & & & \\
\hline " & $13 \ldots$ & $8^{*}$ & 53 & & & & & & \\
\hline " & $14 \ldots$ & $1^{*}$ & 52 & & & & & & \\
\hline “ & $16 \ldots$ & 7 & 59 & & & & & & \\
\hline$"$ & $17 \ldots$ & 4 & 63 & & & & & & \\
\hline " & $18 \ldots$ & 6 & 66 & 3 & 3 & & & & \\
\hline “ & $19 \ldots$ & 0 & 63 & 3 & 6 & & & & \\
\hline " & $20 \ldots$ & 5 & 68 & 0 & 6 & & & & \\
\hline " & $21 \ldots$ & 5 & 71 & 2 & 8 & & & & \\
\hline " & $24 \ldots$ & $2^{*}$ & 69 & 0 & 8 & & & & \\
\hline " & $25 \ldots$ & 9 & 77 & 1 & 9 & & & & \\
\hline “ & $26 \ldots$ & 4 & 81 & 0 & 9 & & & & \\
\hline " & $27 \ldots$ & $4^{*}$ & 77 & 0 & 9 & & & & \\
\hline “ & $28 \ldots$ & 0 & 77 & $1^{*}$ & 8 & & & & \\
\hline " & $29 \ldots$ & 5 & 82 & 0 & 8 & & & & \\
\hline " & $30 \ldots$ & $15^{*}$ & 67 & $1^{*}$ & 7 & & & & \\
\hline May & $1 \ldots$ & 8 & 75 & $1^{*}$ & 6 & & & & \\
\hline & $3 \ldots$ & 0 & 74 & 1 & 7 & & & & \\
\hline “" & $5 \ldots$ & 10 & 84 & 0 & 7 & & & & \\
\hline " & $6 \ldots$ & $11^{*}$ & 70 & 3 & 10 & & & & \\
\hline “ & $7 \ldots$ & 1 & 70 & 1 & 11 & & & & \\
\hline “ & s... & 0 & 68 & 2 & 13 & & & & \\
\hline
\end{tabular}


Colony 27a-Continued

\begin{tabular}{|c|c|c|c|c|c|c|c|c|c|}
\hline \multicolumn{2}{|c|}{ Date } & \multirow{2}{*}{$\frac{\text { Eggs }}{1}$} & \multirow{2}{*}{$\frac{\text { Total }}{68}$} & \multirow{2}{*}{$\frac{\text { Larvæ }}{1}$} & \multirow{2}{*}{$\frac{\text { Total }}{13}$} & \multirow{2}{*}{$\frac{\text { Pupæ }}{1}$} & \multirow{2}{*}{$\frac{\text { Total }}{1}$} & \multirow[t]{2}{*}{ Adults } & \multirow[t]{2}{*}{ Total } \\
\hline May & $9 \ldots$ & & & & & & & & \\
\hline 4 & $10 \ldots$ & $5^{*}$ & 61 & 2 & 14 & 1 & 2 & & \\
\hline$"$ & $11 \ldots$ & 7 & 68 & $2 *$ & 12 & 0 & 2 & & \\
\hline$"$ & $12 \ldots$ & $5^{*}$ & 62 & 1 & 13 & 0 & 2 & & \\
\hline " & $13 \ldots$ & 1 & 62 & 1 & 14 & 0 & 2 & & \\
\hline$"$ & $14 \ldots$ & 5 & 64 & 3 & 17 & 0 & 2 & & \\
\hline " & $15 \ldots$ & 0 & 61 & 3 & 19 & 1 & 3 & & \\
\hline *6 & $16 \ldots$ & $3^{*}$ & 58 & 0 & 19 & 0 & 3 & & \\
\hline$"$ & $17 \ldots$ & 8 & 66 & 0 & 19 & 0 & 3 & & \\
\hline “ & $18 \ldots$ & $7^{*}$ & 53 & 6 & 25 & 0 & 3 & & \\
\hline$"$ & $19 \ldots$ & $1^{*}$ & 52 & $1^{*}$ & 24 & $1^{*}$ & 2 & & \\
\hline$"$ & $20 \ldots$ & $4^{*}$ & 48 & 0 & 23 & 1 & 3 & & \\
\hline$" 6$ & $21 \ldots$ & $6^{*}$ & 42 & 0 & 22 & 1 & 4 & & \\
\hline$"$ & $22 \ldots$ & $1^{*}$ & 37 & 4 & 25 & 1 & 5 & & \\
\hline$"$ & $23 \ldots$ & $2^{*}$ & 34 & 1 & 26 & 0 & 5 & & \\
\hline “ & $24 \ldots$ & 3 & 33 & 4 & 30 & 0 & 5 & & \\
\hline$" 6$ & $25 \ldots$ & $3^{*}$ & 30 & $4^{*}$ & 26 & 0 & 5 & & \\
\hline$" 6$ & $26 \ldots$ & 2 & 32 & 0 & 25 & 1 & 6 & & \\
\hline$"$ & $27 \ldots$ & 2 & 33 & 1 & 25 & 1 & 7 & & \\
\hline$"$ & $28 \ldots$ & $1 *$ & 32 & 0 & 25 & 0 & 7 & & \\
\hline$"$ & $29 \ldots$ & $4^{*}$ & 28 & 0 & 25 & $2^{*}$ & 5 & & \\
\hline$" 6$ & $30 \ldots$ & 0 & 28 & 0 & 24 & 1 & 6 & & \\
\hline$"$ & $31 \ldots$ & 0 & 28 & $1^{*}$ & 22 & 1 & 7 & & \\
\hline June & $1 \ldots \therefore$ & 0 & 28 & 0 & 22 & 0 & 7 & & \\
\hline$"$ & $2 \ldots$ & 4 & 30 & 2 & 23 & 1 & 8 & & \\
\hline$"$ & $4 \ldots$ & 0 & 30 & 0 & 23 & 0 & 8 & & \\
\hline$"$ & $5 \ldots$ & 3 & 33 & $2^{*}$ & 21 & 0 & 8 & & \\
\hline " & $6 \ldots$ & 2 & 35 & $2^{*}$ & 19 & 0 & 8 & & \\
\hline " & $7 \ldots$ & 8 & 42 & 1 & 19 & 1 & 9 & & \\
\hline$"$ & $8 \ldots$ & 1 & 43 & $1^{*}$ & 17 & 1 & 10 & & \\
\hline$" 6$ & $9 \ldots$ & $2^{*}$ & 41 & $3^{*}$ & 1.1 & 0 & 10 & & \\
\hline “ & $10 \ldots$ & 7 & 48 & 0 & 14 & 0 & 10 & & \\
\hline$"$ & $11 \ldots$ & 0 & 48 & 0 & 14 & 0 & 10 & & \\
\hline$"$ & $12 \ldots$ & $1^{*}$ & 47 & 0 & 14 & 0 & 10 & & \\
\hline$"$ & $13 \ldots$ & 1 & 47 & 1 & 15 & 0 & 10 & & \\
\hline$"$ & $18 \ldots$ & $30 *$ & 17 & 0 & 14 & 1 & 7 & 4 & 4 \\
\hline " & $19 \ldots$ & 0 & 17 & $3^{*}$ & 10 & 1 & 8 & $1 *$ & 3 \\
\hline$"$ & $20, \ldots$ & 2 & 17 & 2 & 12 & $3 *$ & 5 & 0 & 3 \\
\hline " & $21 \ldots$ & $4^{*}$ & 13 & $1^{*}$ & 11 & $1^{*}$ & 4 & $1^{*}$ & 2 \\
\hline$\cdot$ & $23 \ldots$ & $12^{*}$ & 1 & $1^{*}$ & 8 & 2 & 4 & 2 & 4 \\
\hline$"$ & $24 \ldots$ & 6 & 7 & 0 & 8 & 0 & 3 & 1 & 5 \\
\hline$*$ & $25 \ldots$ & 1 & 8 & 0 & 8 & $1^{*}$ & 2 & 0 & 5 \\
\hline
\end{tabular}


Colony 27a-Concluded

\begin{tabular}{|c|c|c|c|c|c|c|c|c|c|}
\hline & Date & Eggs & Total & Larvæ & Total & Pupæe & Total & Adults & Total \\
\hline June & e $26 \ldots$ & $1^{*}$ & 7 & 0 & 7 & 1 & 3 & 0 & 5 \\
\hline “ & 27. & 0 & 7 & 0 & 7 & 0 & 3 & 0 & 5 \\
\hline$"$ & 28. & 7 & 14 & 0 & 6 & 1 & 4 & $1^{*}$ & 4 \\
\hline$"$ & $29 \ldots$ & 4 & 18 & 0 & 5 & 1 & 5 & 0 & 4 \\
\hline$"$ & $30 .$. & 2 & 20 & $1^{*}$ & 4 & 0 & 5 & 0 & 4 \\
\hline July & $2 \ldots$ & 4 & 24 & 0 & 3 & 1 & 6 & 0 & 4 \\
\hline “ & $4 \ldots$ & $1^{*}$ & 23 & 0 & 3 & $1^{*}$ & 5 & 2* & 2 \\
\hline “ & 5. & 0 & 23 & 0 & 3 & 0 & 5 & 0 & 2 \\
\hline " & $6 .$. & 0 & 23 & 0 & 3 & 0 & 4 & 1 & 3 \\
\hline “ & 8. . & $7 *$ & 16 & 0 & 3 & 0 & 4 & 0 & 3 \\
\hline$"$ & 9. & 1 & 17 & 0 & 3 & 0 & 4 & 0 & 3 \\
\hline " & $10 .$. & 10 & 27 & $1^{*}$ & 1 & 1 & 5 & 0 & 3 \\
\hline “ & $11 .$. & 0 & 27 & 0 & 1 & 0 & 5 & 0 & 3 \\
\hline$" 6$ & 12.. & 0 & 27 & 0 & 1 & 0 & 5 & 0 & 3 \\
\hline “ & $13 .$. & 8 & 35 & 0 & 1 & 0 & 5 & 0 & 3 \\
\hline " & $14 .$. & 14 & 49 & 0 & 1 & 0 & 5 & 0 & 3 \\
\hline “ & 15. & 0 & 49 & 0 & 1 & $1^{*}$ & 4 & 0 & 3 \\
\hline “ & 16. & 4 & 53 & 0 & 1 & $1^{*}$ & 2 & 1 & 4 \\
\hline " & $17 .$. & 0 & 53 & 0 & 1 & 0 & 1 & 1 & 5 \\
\hline " & $18 .$. & 5 & 58 & 0 & 1 & 0 & 1 & $1^{*}$ & 4 \\
\hline " & 19. & 2 & 60 & 0 & 1 & 0 & 1 & 0 & 4 \\
\hline " & $20 \ldots$ & $10^{*}$ & 50 & 0 & 1 & 0 & 1 & 0 & 4 \\
\hline$"$ & $22 \ldots$ & 0 & 50 & $1 *$ & 0 & 0 & 0 & 1 & 5 \\
\hline “ & $30 \ldots$ & 4 & 52 & 2 & 2 & 0 & 0 & 0 . & 5 \\
\hline Aug. & 1. & $7 *$ & 45 & 0 & 2 & 0 & 0 & 0 & 5 \\
\hline " & 2. & $5^{*}$ & 40 & 0 & 2 & 0 & 0 & 0 & 5 \\
\hline “ & 3. & $4^{*}$ & 36 & 0 & 2 & 0 & 0 & 0 & 5 \\
\hline “ & 5. & $6^{*}$ & 30 & $2^{*}$ & 0 & 0 & 0 & 0 & 5 \\
\hline$"$ & $7 .$. & $6^{*}$ & 24 & 0 & 0 & 0 & 0 & 0 & 5 \\
\hline “ & $9 .$. & 4 & 28 & 0 & 0 & 0 & 0 & 0 & 5 \\
\hline “ & 12. & 2 & 30 & 0 & 0 & 0 & 0 & 0 & 5 \\
\hline “ & $14 \ldots$ & 10 & 40 & 0 & 0 & 0 & 0 & 0 & 5 \\
\hline " & 18. & $4^{*}$ & 36 & 0 & 0 & 0 & 0 & 0 & 5 \\
\hline " & $19 .$. & $6^{*}$ & 30 & 0 & 0 & 0 & 0 & 0 & 5 \\
\hline " & 20. & $7^{*}$ & 23 & 0 & 0 & 0 & 0 & 0 & 5 \\
\hline “ & $21 .$. & $3^{*}$ & 20 & 0 & 0 & 0 & 0 & 0 & 5 \\
\hline " & 22. & 2 & 22 & 0 & 0 & 0 & 0 & $1^{*}$ & 4 \\
\hline “ & $25 \%$ & 5 & 26 & 1 & 1 & 0 & 0 & 0 & 4 \\
\hline “ & $2 \pi$. & $2^{*}$ & 24 & 0 & 1 & 0 & 0 & 0 & 4 \\
\hline " & 28. & 6 & 30 & $1^{*}$ & 0 & 0 & 0 & 0 & 4 \\
\hline Sept & 3. & $8^{*}$ & 22 & 0 & 0 & 0 & 0 & 0 & 4 \\
\hline
\end{tabular}


I was obliged to neglect the colony for several days arıd as a result it perished.

This queen laid a total of 302 eggs, from which but I I adults were reared; iI individuals disappeared in the pupal stage, 30 in the larval stage, and 228 in the egg stage. Not all the young that disappeared in this case were eaten by the queen, as it sometimes happened that they were placed in the condensed moisture around the sponge and spoiled.

It is not possible to get the exact length of the stages in this colony, since some of the eggs disappeared before any had hatched, some of the larve disappeared before any had pupated, and some of the pupæ disappeared before any adults emerged. However, if we assume that the first 6 eggs passed through all the stages and became adults, the stages would be as follows:

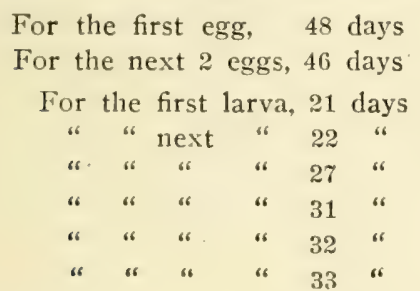

For the next egg, 47 days

For the next 2 eggs, 44 days

For the first pupa, 40 days

$\begin{array}{cccccc}\text { " } & \text { " next } & \text { " } & 39 & \text { " } \\ \text { " } & \text { " } & \text { " } & \text { " } & 34 & \text { " } \\ \text { " } & \text { " } & \text { " } & \text { " } & 33 & \text { " } \\ \text { " } & \text { " } & \text { " } & 32 & \text { " }\end{array}$

\section{COLONY 30}

This queen was taken as a solitary female from her cell in a corn field by G. E. Sanders on May 7. At first I had her in the same nest with another queen taken the same day. On May I8, 3 eggs appeared in the nest, and on May 19, 2 more. I then removed one queen and the 5 eggs. The remaining queen laid no eggs until May 26.

COLONY $30^{*}$

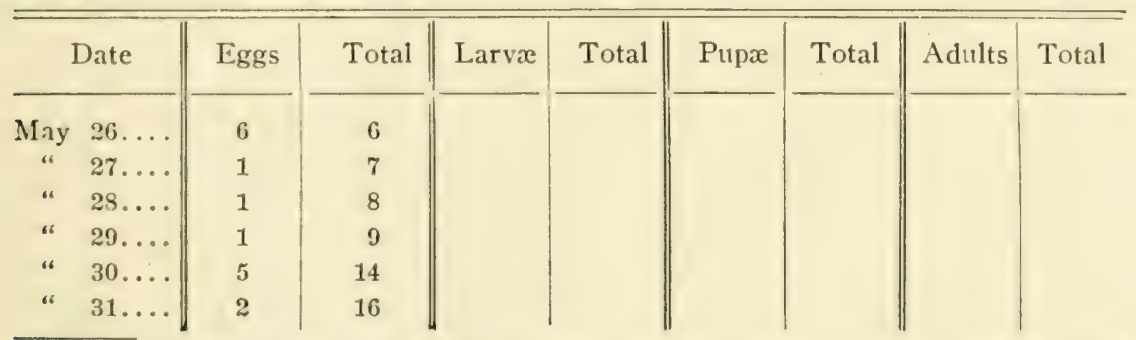

*In this table as heretofore, the asterisk signifies missing; the dagger, injured or destroyed. 
18

Colony 30-Continued

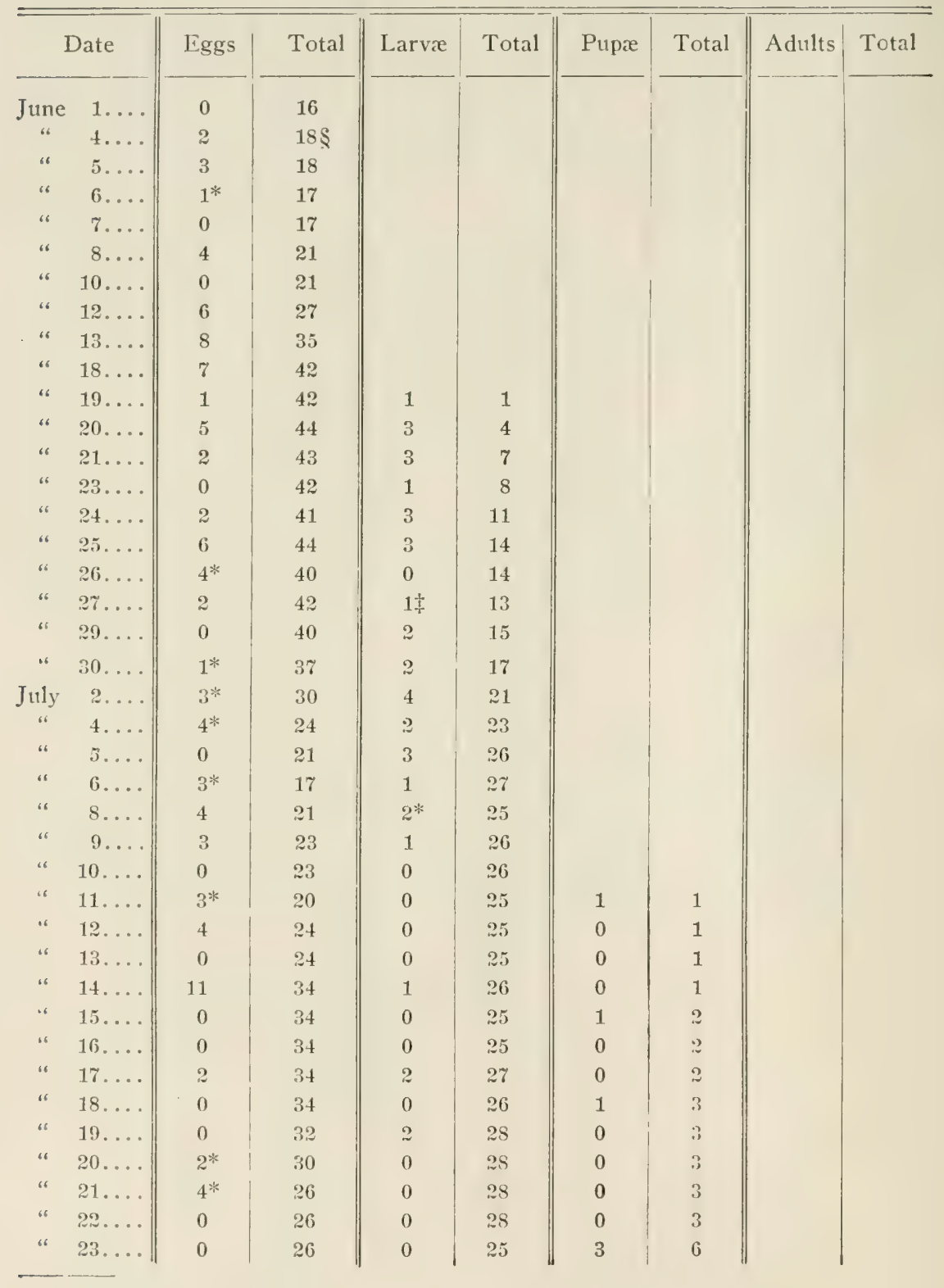

$\$ I$ destroyed 3, leaving 15. 
Colony $30-$ Concluded

\begin{tabular}{|c|c|c|c|c|c|c|c|c|c|}
\hline \multicolumn{2}{|c|}{ Date } & \multirow{2}{*}{$\frac{\text { Eggs }}{1^{*}}$} & \multirow{2}{*}{$\begin{array}{l}\text { Total } \\
25\end{array}$} & \multirow{2}{*}{$\frac{\text { Larvæ }}{1^{*}}$} & \multirow{2}{*}{$\frac{\text { Total }}{23}$} & \multirow{2}{*}{$\frac{\text { Pupæ }}{1}$} & \multirow{2}{*}{$\frac{\text { Total }}{7}$} & \multirow[t]{2}{*}{ Adults } & Total \\
\hline “ & $24 \ldots$ & & & & & & & & \\
\hline “ & $25 \ldots$ & 0 & 25 & 0 & 23 & 0 & 7 & & \\
\hline “ & $26 \ldots$ & 0 & 24 & 1. & 24 & 0 & 7 & & \\
\hline “ & $29 \ldots$ & 9 & 32 & 1 & 24 & 1 & 8 & & \\
\hline Aug. & $1 \ldots$ & 0 & 32 & 0 & 24 & 0 & 7 & 1 & 1 \\
\hline$"$ & $3 \ldots$ & $8^{*}$ & 24 & $2^{*}$ & 22 & 0 & 7 & 0 & 1 \\
\hline “ & $4 \ldots$ & 0 & 24 & 0 & 22 & $1^{*}$ & 5 & 1 & 2 \\
\hline “ & $5 \ldots$ & 0 & 24 & 0 & 22 & 0 & 5 & 0 & 2 \\
\hline " & $6 \ldots$ & 0 & 24 & 0 & 21 & 1 & 6 & 0 & 2 \\
\hline “ & $7 \ldots$ & 0 & 24 & 0 & 20 & 1 & 6 & 1 & 3 \\
\hline “" & $9 \ldots$ & 0 & 24 & 0 & 19 & 1 & 7 & 0 & 3 \\
\hline “ & $10 \ldots$ & $4^{*}$ & 20 & $2^{*}$ & 17 & $1^{*}$ & 5 & 1 & 4 \\
\hline “ & $11 \ldots$ & 0 & 20 & 0 & 17 & 0 & 3 & 2 & 6 \\
\hline “ & $12 \ldots$ & 0 & 20 & 0 & 17 & 0 & 2 & 1 & 7 \\
\hline “ & $14 \ldots$ & 0 & 20 & 0 & 16 & 1 & 3 & 0 & 7 \\
\hline “ & $16 \ldots$ & 0 & 20 & 0 & 15 & 1 & 4 & 0 & 7 \\
\hline “ & $17 \ldots$ & $3^{*}$ & 17 & $3 *$ & 12 & 0 & 3 & 1 & 8 \\
\hline “ & $13 \ldots$ & $2^{*}$ & 15 & 0 & 11 & 1 & 4 & $1^{*}$ & 7 \\
\hline “ & $19 \ldots$ & 0 & 15 & 0 & 11 & 0 & 4 & 0 & 7 \\
\hline “ & $20 \ldots$ & 0 & 15 & 0 & 10 & 1 & 5 & 0 & 7 \\
\hline “ & $25 \ldots$ & 7 & 22 & $1^{*}$ & 9 & 0 & 5 & 0 & 7 \\
\hline “ & $27 \ldots$ & 0 & 22 & $1^{*}$ & 8 & 0 & 5 & 0 & 7 \\
\hline$"$ & $30 \ldots$ & 6 & 28 & $2^{*}$ & 5 & 1 & 6 & 0 & 7 \\
\hline Sept. & $3 \ldots$ & 0 & 28 & 0 & 5 & 0 & 6 & 0 & 7 \\
\hline$"$ & $21 \ldots$ & $14^{*}$ & 14 & $3^{*}$ & 2 & $3^{*}$ & 1 & 2 & 9 \\
\hline “ & $28 \ldots$ & $4^{*}$ & 10 & 0 & 2 & 0 & 1 & 0 & 9 \\
\hline Oct. & $3 \ldots$ & 0 & 8 & 2 & 4 & 0 & 1 & 0 & 9 \\
\hline “ & $7 \ldots$ & 0 & 8 & 0 & 4 & 0 & 0 & 1 & 10 \\
\hline
\end{tabular}

'There was no further development of this colony, as the weather became too cool. Several adults died. December 2, I transferred the colony to a warm room. December 20 the queen began laying again, and by January Io she had laid I 7 eggs. January ig the queen died and the colony was discarded.

Assuming that the first 6 eggs developed into the first 6 adults, the lengths of the various stages are as follows:

For first egg, $2+$ days; for next 3 eggs, 25 days; and for next 2, 26 days.

For first larva, 22 days; for next one, 25 days; for next one, 28 days; for next one, 33 days; and for next (2 larva), 32 days.

For first pupa, 2 I days; for next (2 pupx), 20 days; for next pupa, is days; and for next ( 2 pupre), ig days. 
This gives for the first 6 eggs an average time of 25 days; for the first 6 larvæ, 28.6 days; for the first 6 pupæ, I9.5 days.

In colony $27 b$ the average time for the first 6 eggs is 44.5 days; for the first 6 larvæ, 19.5 days; and for the first 6 pupæ, 23 days. In colony $27 a$ the average time for the first 6 eggs is 46 days; for the first 6 larvæ, 28 days; and for the first 6 pupæ, 34.5 days.

The queen in colony 30 , laid a total of 1 IO eggs, from which II adults were reared. Five individuals disappeared in the pupal stage, I 8 in the larval stage, and 64 in the egg stage.

\section{COLONY 28}

April 5, I took a solitary queen from her cell in a corn field and placed her in a Fielde nest under normal temperature conditions. She began to lay May i6. By August 25, when she died, she had laid 54 eggs, from which but one adult was reared. Twenty-four individuals disappeared in the egg stage, 27 in the larval stage, and one in the pupal stage. Forty-eight of the 54 eggs were laid between May I6 and June 2. After that date the queen did not seem to do well. The lengths of the egg periods for the first 6 eggs are as follows: for the first (I), 25 days; for the next (I), 24 days; and for the next (4), 25 days.

Because of the fact that this queen did not take good care of the young, most of them perished and I could not get the lengths of the stages.

\section{COLONY I8}

This queen was carried over winter in a Fielde nest in a warm greenhouse. She began laying April io. By June 27, when she died, she had laid 93 eggs. But 3 pupæ were reared from these, 29 disappeared in the larval stage, and $6 \mathrm{I}$ in the egg stage. The lengths of the egg stages for the first 6 eggs are as follows: for the first 2 eggs, 26 days; for the next 4 eggs, 23 days.

This gives an average of 24 days as the length of the egg period for the first 6 eggs. No eggs disappeared in this nest until after the larvæ appeared, so the stages here may be taken as exact.

\section{COLONY I $8 \mathrm{C}$}

This queen was taken in the fall and carried over winter in a warm greenhouse, but on March 25, before she had laid any eggs, was transferred to a room where the temperature was normal. She 
began laying April 27, and by June Io, when she died, had laid 45 eggs; but they kept disappearing from time to time, and none of them hatched.

\section{COLONY I $8 d$}

This queen was taken at the same time as the one in colony I $8 c$, and kept under the same conditions. She began laying the same day, April 27, and by July 3I, when she died, she had laid II4 eggs, but for the same reason as above, none of them hatched.

\section{COLONY $26 a$}

This queen was kept over winter in a warm greenhouse. She began laying February 27, and by September 3 had laid r40 eggs, from which but two adults were reared. As so many disappeared at different times I could not get the lengths of the various stages.

A large number of the queens which I used for starting colonies lived only a few weeks or months and did not bring any young to maturity, although all laid eggs. Some of them seemed to eat a large percentage of the eggs, while others simply allowed the eggs to spoil. Three other queens may be mentioned. The one in Colony B, No. I $c$, taken in April and kept under natural conditions, produced 2 workers and II larvæ by September I5. The egg period for the first 2 eggs was 24 days. The egg stages for the first 3 larvæ were 2 I, 24, and 25 days, respectively. The pupal period for the first adult which emerged was 26 days. ber 7 .

In Colony B, No. I $d$, the queen produced 9 workers by Septem-

Colony B, No. I $I$ was kept under practically normal conditions. The queen was taken about the middle of April and kept with some others until June 24, when I placed her in a Barth nest, made by placing a glass cylinder 3 inches high and 3 inches in diameter inside a cylindrical glass jar 4 inches high and 4 inches in diameter, and filling the space between the cylinder and the jar with moist sand. The top was then covered with a layer of cotton batting, and this was held down by a pane of glass. The queen began to burrow at once, and by June 30 had made a complete cell at the bottom of the sand and had deposited several eggs. In forming her cell the queen had completely closed the burrow by means of which she reached the bottom of the sand. With such a nest it was impossible to take 
daily observations as to the number of young, but I have the following notes on the development of the colony:-

August 3, I count I5 cocoons and see a number of eggs and larvæ; Aug. 8, I count 2I cocoons; Aug. I7, three callows have emerged; Aug. 20, there are 5 callows today.

August 25. There are at least Io callow workers today. They are very active and have excavated a tunnel nearly 6 inches in length around the buttnm of the glass jar. They have moved some of the brood about $1 \frac{1}{2}$ inches from the original cell of the queen.

August 28. There are I5 callow workers. Very active. Their main tunnel is about ro inches in length and is started upward. It is half-way to the top of the cylinder.

August 29. They have excavated to the top of the sand.

I did not break up this nest in order to get the exact count, but the approximate count at the end of the season was 15 to 17 workers and I larva. No pupie or eggs.

The seven cases in which the queen succeeded in founding a colony and living through the season are as follows.

\begin{tabular}{c|c|c}
\hline Number of colony & Number of workers produced & Total number of eggs \\
\cline { 2 - 2 } $27 b$ & 11 & 222 \\
$27 a$ & 27 & 302 \\
30 & 11 & 110 \\
$26 a$ & 2 & 140 \\
B, No. $1 c$ & 2 & \\
B, No. 1d & 9 & \\
B, No. 1l & 16 & \\
\hline
\end{tabular}

This gives an average of II workers produced by a queen in one season, with a maximum of 27 . The average number of eggs laid by the queens in the four cases in which I was able to get the entire count, is 193.5. The first-year workers are very small, on account of insufficient nourishment.

The above data show that sexual forms are not produced the first year. It is not at all likely that they are produced the second year because of the very greatly increased amount of nourishment required for producing them. After the second year the average and maximum colonies probably increase very rapidly, as the number of workers is then large enough to provide plenty of nourishment for the queen to lay a much larger number of eggs. 
The following data show how much more prolific the queen is when she is well nourished by a large colony:-

July 7 , I took the old queen from a large colony of $L$. niger americamus under a stone and brought her to the laboratory. At IO:00 a. $\mathrm{m}$. I placed her in a vial by herself. By 4:00 p. m. she had laid I25 eggs, an average of $3 \mathrm{I}$ an hour, or one every two minutes. I removed her from the vial and placed her in a Petri dish with five workers from the same colony.

July 9, 9:00 A. M. Moisture from the sponge had collected in the bottom of the Petri dish, and the queen and workers were nearly drowned. The queen, however, had laid 168 eggs. I placed her in a dry vial. She began laying again at II:45 and by $2: 00 \mathrm{p}$. m. had laid 48 more eggs. Thus in a little more than two days this queen laid 34I eggs, or more than the average of the total number laid by the four first-year queens in an entire season.

August I3, I took the old queen from a very large colony of $L$. niger americanus, brought her to the laboratory, and placed her in a Petri dish at $5: 30$. I watched her continuously for 30 minutes, during which time she laid eggs, at fairly regular intervals, at the rate of about one every two minutes. By 6:00 p. m. she had laid I6 eggs. By II o'clock the following morning she had laid I66 eggs, an average of 9.5 eggs an hour. Between I I :OO A. M. and I 2 :O0 M. she laid 6 more eggs.

By the beginning of the third year the average colony is so large that, if suitably located, it can furnish sufficient nourishment to cause the queen to produce a much larger number of eggs and also to feed the increased number of larva. Such a colony might be sufficiently large for the workers to feed a certain number of the larvæ heavily enough to produce, not workers, but winged females. Some colonies, however, as those that produced but two workers the first year, might be no larger at the end of the second or even at the end of the third year than the more fortunate ones at the end of the first year. Such colonies would probably not produce females until the fourth or fifth year or even later, on the assumption that the difference in the production of workers and females is a difference in nutrition, which I believe to be the case. If a colony containing brood but no queen is supplied with an abundance of food, they will segregate a number of the larvæ, feed them more heavily than the others, and cause them to produce queen larvæ. 


\section{HIBERNATION}

With the approach of cold weather the ants become inactive and gather together in a few of the main galleries of the nest with their larvæ, occupying at that time a very limited region compared with the large area occupied by their extensive tunnels in the summer time. I have never found anything but queen, workers, and larvæ in the nests in late fall, winter, or early spring. I have never found males or winged females of this species in winter, although it is quite common to find the winged forms of some other species in the nests during the winter. This shows that the winged forms all leave the nests in the summer or autumn. My observations show that the ants are very little, if any, deeper in the soil in winter than in summer. In fact, they seem to use their largest summer tunnels for their winter quarters. The first few days of January, I909, were very warm. The frost was out of the ground in the open fields so the farmers could plow. January 4, I followed a plow in an old cornfield, and found in the bottom of the furrows a large number of nests of L. niger americamis exposed, just as one finds them in the spring and summer. The ground was so cold that the ants were quite stupid and very inactive, and they were huddled together in masses with their larvæ. Such masses could be picked up in places by handfuls, when the ants would very slowly crawl about over one another. They were far too stiff and inactive, however, to have moved with their large bunches of larvæ from the deeper galleries during those few warm days, so they must have been in these same galleries during the previous part of the winter, and would have remained there all the rest of the cold weather. As the ants were warmed by the heat of the hand, or that of the laboratory, they soon became as lively as ever and resumed their normal activities.

Drouth will drive the ants down into the soil much deeper than cold. In very dry weather I have followed their tunnels to a depth of 22 inches, and often in the summer time many of their main galleries are eight to ten inches deep. In the fall of 1909 I marked


various times during the following winter examined one or more of them. I found the ants at the depths one finds them during the summer, that is, from just below the surface to eight and ten inches down. Most of the ants and their larvæ were from four and a half to seven inches down, although I found some not more than two inches below the surface when the ground was frozen to a depth of five and six inches. When the ground was frozen the walls of the 
cells were covered with a thin layer of ice, inclosing the ants and their larve in an icy cell. These ants on being thawed out became active immediately. In two of these nests I found eggs of the cornroot louse, Aphis maidiradicis Forbes. These were in little packets in cells by themselves, not with the larva. In the nest containing the largest number of eggs, the cells containing the eggs of the plantlouse were four and a half inches below the surface. By working carefully with a trowel I was able to get the largest packet of eggs out with very little dirt, and on taking them to the laboratory and counting them I found that I had thus separated 894 eggs, and as there were other smaller packets in the nest, there was probably twice that number of aphid eggs in the nest altogether. These eggs had probably been laid by oviparous females which had been carried down into the galleries by the ants. November IO, I found one oviparous female and some eggs in the galleries of a large colony about 5 inches below the surface, although the main galleries of this nest extended downward to a depth of from $\mathrm{I} 2$ to $\mathrm{I} S$ inches. In such nests the youngest larva were in the deepest portions of the nest, while the larger ones were nearer the surface.

The fact that larva are found in the nests during the winter shows that the length of the larval period is variable, depending upon temperature, and also probably upon other factors, as nourishment, moisture, etc. If a colony containing a large number of larvæ all of about the same size be fed heavily, the workers do not feed the larva uniformly, but separate a relatively small number from the rest and give them much more nourishment, which causes them to pupate much sooner. Then they separate a few more and feed them in the same way. The latter may have hatched as early as the former, but their larval period is much longer.

In one of my colonies some of the larva remained as stich for more than a year. This colony was collected November 6, and contained about 300 workers and a large number of larva but no queen. I kept them for a while in the greenhouse mentioned above, but about the middle of the winter transferred them to a warm room and fed them heavily. The larva began to grow rapidly and on March 2, 25 of them spun cocoons. The next day there were between 75 and $I 00$ cocoons in the nest, and new cocoons were formed every day from that time. It was interesting to see how busy the ants were when so many larva were spinning cocoons at once. Every larva, when it was ready to spin a cocoon, was covered with fine pieces torn from the sponge, or other debris, in order to give it something to which to attach its first silken threads. As though to 
avoid a useless expenditure of labor, these larvæ were not scattered about indiscriminately, but were mostly placed in one heap consisting of seven or eight layers reaching from the floor to the ceiling of the nest, so that the same pieces of debris would serve for more than one larva. One evening I placed a piece of boiled lean beef, about I cm. square and half as thick, in the nest for food. By the next morning it had been torn into shreds, and these had been used by the ants in covering the larvæ. If the larvæ failed to attach their threads the result was naked pupæ. I saw one larva that had accidentally wriggled out of its half-spun cocoon; later it became a naked pupa. When a cocoon was finished the workers removed it from the pile, carefully cleaned off the bits of sponge, meat, etc., and placed it with others in a clean pile. When the adult is ready to emerge the workers remove the cocoon from the pile, bite it open, and help out the young callow. The workers had placed thirty of the larvæ in one pile, and had fed them so heavily that they were forming queen larvæ. By March Io these were about twice the size of the full-grown worker larvx. March I5, this nest showed the most distinct grouping of the inhabitants of the nest I have ever seen. There were seven distinct groups. These were (I) the thirty queen larvæ, (2) the buried larvæ spinning cocoons, (3) a small bunch of cocoons with the naked pupæ (there were I 5 naked pupæ), (4) all the rest of the cocoons (more than IOO), (5) the nearly full-grown larvæ which were feeding heavily (these had their anterior ends pressed against a bit of egg, and with a lens one could see their jaws working as they ate their food), (6) the youngest larvæ, but little larger than the egg, and (7) those larvæ intermediate in size between those of groups 5 and 6 . On March 26 the first three adults emerged and the next day seven more. This gives a period of 24 and 25 days for these pupx. 'The empty cocoons were carried over to one corner and placed in the waste heap. On April I, one of the queen larvæ was partly eaten, and from that time these gradually disappeared, one or two a day, until May 5, when the last two were eaten with the exception of one that had spun a cocoon on April I9. During all this time I kept the colony well supplied with food consisting of sugar-water, egg yolk, boiled beef, and insect food such as white grubs, pieces of flies, beetles, etc. On May 5 the queen pupa was taken out of its cocoon, formed on April I9. 'The following notes show something of the rate and time of deposition of chitin:-

May Io. The queen pupa shows a deposit of chitin at the edge of the mandibles, making a brownish line along the teeth. All the 
rest of the surface is white excepting the compound eyes and ocelli, which are already dark, - the compound eyes very dark, and the ocelli a light brown.

May II. The pupa has acquired a light brown tint all over. The teeth of the mandibles are darker and the brown is beginning to go back over the rest of the mandible.

May I2. The general color of the body is a little darker.

May 13. Still darker.

May I4. The queen has emerged.

This gives a period of 25 days for the queen pupa, the same as that for the first few worker pupx. This female never seemed to be healthy, and died on June 30 .

There were no more larvæ produced by this colony. The rest of the larvæ continued to pupate and adults continued to emerge until July 7. On that date there were no more cocoons in the nest, and none of the larva which were in the nest over winter. All the adults which emerged were workers except the one female. There were no males.

April 4, I noticed for the first time a bunch of 40 or 50 eggs. These were of course worker eggs, as there was no queen in the nest. By May I there were several hundred eggs. May I I I estimated the number to be at least 500 , and quite a number of them had already hatched. By July 7 all the eggs had hatched, so there were in the nest at that time only the workers and 500 or more larvæ, all being the offspring of worker eggs. No more eggs were laid and none of the larvæ pupated during the rest of the summer nor the following winter, although I kept them all the time in a warm room and gave them plenty of food. The first cocoons were spun on July 4, I9IO, when 8 of them were formed. The exact length of the larval period could not be determined, but it must have been more than a year, since a considerable number of the eggs had hatched by July 7, I909. July I8, I9Io, there were 30 cocoons in the nest and a small bunch of worker eggs were laid. It had been over a year since any eggs had been laid in the nest. More eggs were laid later on-about 50 or 60 altogether; not nearly so many as the year before. However, a large number of the workers had died during the year and many of the larve had been eaten, so that the colony was not nearly so large as the year before. July 24 the first adult emerged; a second, July 25; a third, July 26; and a fourth, July 27. These were all males. This gives a pupal period of 20, 2I, 22, and 23 days for these males. 'This nest was examined every day during the summer. Cocoons continued to be formed and adults 
continued to appear until the last of September, and although I watched carefully for the appearance of callow workers, every adult proved to be a male. These males did not seem to do well, as there were never more than 15 or 20 males in the nest at the same time; but there were certainly more than Ioo that emerged. This agrees with the general opinion that the offspring of unfertilized eggs of ants, as well as of bees, are always male, although Mrs. Comstock (Wheeler, 'o3) obtained normal workers from worker eggs. In a small queenless colony of Formica schanfussi that I watched, the offspring from worker eggs were all males. This brings up the interesting question as to whether the fertilized eggs of a fecundated queen ever produce males. Certainly they do not the first year, and most probably not the second. It is worthy of note that the same conditions which will develop winged females in a colony, that is, optimum conditions of food, temperature, and moisture, will also cause the workers to lay eggs and thus bring about the production of both the sexual forms.

The probable life of a colony is but a year or two years longer than that of the queen which founded it. After the queen dies the eggs laid in the nest will all be worker eggs and produce males. In strong colonies a few eggs would also be laid the second year, but the next year the colony would perish, or perhaps serve as a host for some species whose queen is temporarily parasitic upon $L_{\text {. }}$ niger americanus, as I have shown to be the case with Lasius umbratus var minutus ('Tanquary, 'II). Or it may serve as the host of young dealated, fertilized females of the same species, just descended from their nuptial flight, as I have shown that at times such queens may be adopted by small queenless colonies of this species ('II). The death of the queen the year before must account for my finding large colonies of this species which contained many hundreds of males but no females.

\section{SUMMARY}

I. Dates for which I have evidence of nuptial flights of Lasius niger annericanus are September 5, 9, IS, 20, I9 to 29, October 4, II, and 18.

2. The flights generally occur in the afternoon between 3 o'clock and 6 o'clock.

3. 'The time of a flight is partly determined by weather conditions.

4. Fertilization probably takes place in the nest.

5. The young queens eat a large proportion of their eggs. 
6. The length of the different stages varies with conditions. The larval stage may extend over more than a year.

7. The average number of adults produced in a season was eleven, and the maximum number, twenty-seven.

8. The number of eggs laid by a queen depends upon the amount of nourishment she receives. In large colonies she may lay at the rate of more than one hundred eggs per day.

9. During the winter, nests of this species contain only dealated females, workers, and larvæ.

IO. The winter quarters of this species are at about the same depth as those of the summer.

II. Ants taken from winter quarters in a frozen condition resume their normal activities at once upon being thawed out.

I2. A single colony of $L$. niger americants may carry through the winter more than one thousand eggs of Aphis maidiradicis.

I3. A small percentage of the pupæ of this ant are naked, some of them owing to a failure of the larvæ to attach their first silken threads. Naked pupa occur among those of a first-year colony as well as in older colonies.

I4. The workers seem to be able to produce queen larva by furnishing plenty of food.

I5. The workers will eat some of the larvæ, even though plenty of food is provided.

I6. If a colony of workers is heavily fed it will produce a large number of eggs.

I7. The adults from such eggs in all my colonies were males.

I8. A colony probably does not continue to exist longer than the second year after the death of the queen. Such a colony may adopt a young fertilized female of the same species just descended from the nuptial flight, or may serve as host for the queen of another species that is temporarily parasitic upon Lasins nigor americanus.

19. Colonies of Lasius niger americanus are founded in one of two ways; (I) by the typical method or (2) by the adoption of recently fertilized females by a small queenless colony.

\section{ADDITIONAL NOTIS}

In one of my Fielde nests I noticed one day a larva with its anterior end lying against one of the eggs, which it seemed to be eating in the same way as described earlier for the small bits of egg yolk. On examining with a lens I could see that about one half of the egg 
was already eaten and that the larva was still feeding. This may be one reason why the workers keep the eggs and the larvæ separate.

The sense of taste seems to be well developed in ants. They quickly discriminate between honey and sugar water and much prefer the latter to the former. On one occasion, instead of using sugar water, as usual, I placed a drop of honey in each nest. Generally the drop of food was discovered almost immediately and within a few minutes surrounded by the eager workers. On this occasion I examined the nests a few minutes after the introduction of the food, and in only seven out of the 26 colonies were there any ants at the honey, and only a few in those cases. On another occasion I introduced a drop of honey and sugar water at the same time in the light cliamber of the Fielde nest containing a large colony. The honey was placed nearer the opening into the dark chamber where the ants stayed, while the sugar water was placed farther beyond it and near the refuse heap. The water was quickly surrounded, while only a few ants stopped at the honey, although they had to go around the honey to get to the sugar water. After a few minutes some of the ants began, as is their custom, to carry the dead ants, empty pupacases, etc., from the refuse heap and place in the liquid food, but in this case it was very striking to see the way in which the ants carried bits of debris around the sugar water in order to deposit them in the honey, while the feeding ants were passing around the honey to get to the sugar water. After a few minutes there were $\mathrm{I}_{3}$ dead ants placed in the honey and only $\mathrm{I}$ in the sugar water. This shows clearly that the purpose of such behavior on the part of the ants is to cover up objectionable substances and not to enable them the better to get at the food.

The queens do not often eat from the food chamber as the workers do, but I have seen them drinking sugar water a number of times. They will also cover the sugar water with bits of debris, and in some cases the queens stuck to the cover pane small pieces which they had torn from some black blotting-paper I had in the nest, as though to help shut out the light. They will also bury their larva when the latter are ready to spin their cocoons and will clean the cocoons after they are finished.

The ants often use bits of sponge and other debris to block up the passageway between the two chambers of a Fielde nest as though to shut out the light from the other chamber. In the same way I have had colonies of Aplianogaster fulva block up a passageway to shut out queens of $A$. tennessensis which I was using for temporary parasitism experiments. Is this intelligence? 
Although most of the winged forms of this species leave the nests in summer or early autumn, I have a note from Messrs. W. P. Flint and G. E. Sanders, reporting the finding of winged females in a nest at Galesburg, Ill., October 29, I909.

\section{Experiments on the Trail Formation and Orientation of The Common House An', Monomorim pharaonis L.}

The little creatures that form the subject of these experiments forced themselves upon my attention by interfering seriously with my regular work and making themselves a general nuisance in the laboratory. They had a nest in some inaccessible place in the walls of the building, from which they formed regular trails to any substance in the laboratory, such as insect specimens, fruit, meat, sugar, etc., which they found suitable for food. A piece of fruit left lying on a desk in the laboratory was sure to be found by some wandering worker, and in an hour or so a regular trail would be formed leading to it, along which hundreds of the little workers would pass to and fro in the course of a few minutes.

For my regular experiments I was keeping in Fielde nests a number of colonies of the common corn-field ant, Lasius niger americamis, which I often fed with sugar dissolved in water. The little $M$. pharaonis could crawl in under the roof-panes of these nests to the food provided for the Lasius colonies and many times caused the death of an entire colony in a single night. I do not know just how the $L$. americamus ants were killed. I never saw a $M$. pharaonis attack a living worker of the former species, but in some way its presence in the nests in such large numbers so irritated the corn-field ants as to cause their death. I have seen workers of $M$. pharaonis attack a queen of $L$. americanus that was already weakened to such an extent that she was unable to right herself when lying on her back.

The regularity of the trails, the closeness with which they were followed, and the extreme sensitiveness of the ants to slight breaks in their trail, made by rubbing the finger across it or placing some odoriferous substance or even a small piece of clean paper upon it, interested me, and induced me to perform some experiments to determine whether they depended entirely upon a chemical sense, located in the antennæ, to find their way, or whether they possessed also a sense of direction. While I was working on this problem other questions of a similar nature presented themselves which I tried to answer by experiments, some of which are given below. 
After a number of preliminary experiments of one kind or another I used the following simple device to serve my purpose. I took an ordinary spindle-file with a base $2 \mathrm{I} / 2$ inches square, from the center of which extended upward, 7 inches in height, a cylindrical rod $1 / 8$ inch in diameter. On the sharp point of this rod I stuck a circular piece of cork, I inch in diameter, which served as a support for a bottle containing sugar dissolved in water. Before placing the bottle of sugar-water on the cork I would cause the ants to form a trail to the bottle sitting on my desk; then I would replace the bottle with the file having the bottle on top, ustrally with 50 to Ioo ants feeding from it. So many of these ants in wandering back from the bottle of sugar-ivater would meet the ants at the base of the file, that soon the trail would be continued up the rod to the bottle.

\section{EXPERIMENT NO. I}

After a distinct trail was formed, I removed the cork with the bottle just long enough to thrust the rod through the center of two pieces of clean white note-paper, $23 / 4$ inches square, one of which I placed one third, the other two thirds, the distance up the rod, so that the whole apparatus now had the appearance shown in the figure.

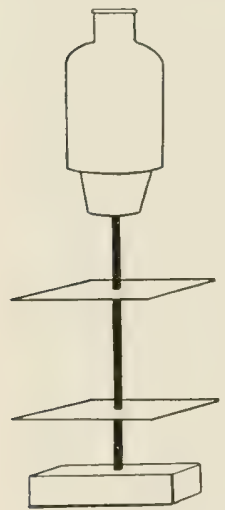
In order to get down, the ants now had to go out to the edge of the papers on the upper side and return to the rod on the under side. It was several hours before they formed a distinct trail, since they wandered about in confusion on the upper side of the papers and did not like to go over the sharp edges. When the trail was formed it led down the side of the bottle nearest the nest, down the rod on the same side, then in a straight line out to the middle of the edge of the paper towards the nest, back to the rod on the under side in the same line and over the lower paper in the same way, so that the trail on it was exactly beneath the one on the upper paper, then on down the rod and back to the nest.

After a good trail was formed I turned the top paper a few degrees to the right when no ants were on it. The next ants that reached the paper, both from above and from below, instead of following in the same direction followed the old trail, which extended at an angle of a few degrees from its former direction. I then turned the lower paper a few degrees to the left with the same result, that is, the ants followed the trail. I continued turning the top paper to 
the right and the lower to the left until there was a difference of I8o degrees in the direction of the trails on the two papers. The ants still followed the trail. I continued turning the papers until both trails again led the same way but exactly opposite to their first direction, with the same result. Then I tried turning the papers through an angle of 90 degrees and even i8o degrees at one turn, but always with the same result. The first ants that reached the paper after turning it through so large an angle, were a little confused by the slight break in the trail, and sometimes a few of them would get lost and wander about for a while, until, striking the trail, they would start off in a straight line.

The above experiment I repeated a great many times and always with the same result; the ants followed the trail absolutely without regard to change of direction. This shows that, at least after the trail is formed, the ants, if they do possess a sense of direction, are not guided by it in finding their way back to the nest, but slavishly adhere to their trails, although the fact that the trails were formed on the side of the bottle and towards the edges of the paper nearest the nest indicates that in forming their trails a sense of direction may play some part. Later on I repeated the experiment, using circular cardboard disks, 4 inches in diameter, instead of square pieces of paper, and found that the trails were formed in the same way, although quite often there was a difference of a few degrees in the direction of the trails on the two disks, and in some places they even extended in opposite directions. Usually, however, they extended in nearly the same direction.

\section{EXPERIMENT NO, 2}

To determine whether the direction from which the light comes influences the ants in finding their way.

In some of the foregoing tests the apparatus was sitting near a window, so that when the disks were turned through an angle of I 80 degrees the relation of the light to the trail was exactly reversed. This, however, made absolutely no difference in the behavior of the ants.

In order to make another test, one evening, at $7: 30$, I placed an incandescent light 2 feet from one side of the apparatus. At 8:45 p. m. I changed it to about the same distance from the opposite side. So far as I could judge from their behavior, the ants did not even notice the change. I repeated this experiment many times, and always with the same result. 


\section{EXPERIMENT NO. 3}

Can ants of this species recognize a trail laid down by other individuals belonging to the same or to another colony?

It would seem in the highest degree improbable that each one of these hundreds of ants following the trail did so only after it had found the food independently or had followed other ants and laid down its own trail, but Miss Fielde in "Further Study of an Ant" ( I9OI) makes the statement concerning another species, Aphanogaster fulva picea, that each ant lays down its individual trail, which can not be recognized by other ants of the same colony. In order to test this point with $M$. pharaonis I brought seven ants from another room of the building and placed them, one at a time, on one of the cardboard disks. In every instance the ant wandered about until it struck the trail, which it then followed, sometimes to the nest and sometimes to the food. To be sure, the ant did not in every instance, especially when excited, recognize the trail the first time it struck it, but almost without exception the trail was recognized sooner or later and followed. It is very improbable that these ants had been on the trail before; but to make the test more sure I isolated a number of them for several days, during which I caused trails to be formed on new disks. Placing these ants on the disks I found that they followed the trail just as the others had done. In each instance I was careful to place the ants to be tested on the disks at a time when there were no other ants there. These experiments were also to serve another purpose and will be referred to again.

To find out whether ants from one colony could recognize a trail laid down by ants of a different colony, I had a friend whose pantry was infested by this same species, and whose house was at least a quarter of a mile from the insectary, bring me a number of them in a bottle. I found that they recognized the trail just the same and started to follow it, but that they were invariably attacked and killed when they met the other ants.

\section{EXPERIMENT NO. 4}

To determine the length of time a trail can be recognized after it has ceased to be 11 sed.

Jamıary 25-3:05 P.M. I remove the top disk, B, having previously marked the position of the trail by placing a small ink spot on either side of it.

4:I5 P.M. I replace disk B in such a way that the trail leads out in the opposite direction from what it did before, and in the opposite 
direction to that on the lower disk. With almost no confusion the ants, both coming and going, led out over the old trail. The disk has been removed I hour and to minutes.

January 26.-8:I7 A.M. I remove disk B again.

I $:$ I 7 A.M. I replace disk $B$ so that the direction of the trail extends at an angle of 90 degrees from the one on the lower disk. Without hesitation the ants start out from the stem over the old trail, but the first three from each direction go only two thirds of the way to the circumference and then turn back. The fourth ant from above goes over the edge, hesitating a little, and meets the ant on the under side. After that the ants go on as before. The disk has been removed 3 hours.

I I :20 A.M. I remove the lower disk, A.

$5: 30$ P.M. I so replace disk A that the trail on it extends in the opposite direction from that on the other disk. The first ants that reach the disk appear lost and wander about, but still seem to recognize the trail faintly when they cross it. In about a minute, one ant on the upper side of the disk follows the trail to the edge and goes to the under side, where it follows the trail on to the nest. Not all the ants seem to be able to recognize the trail, and many wander about over both surfaces of the disk, sometimes following it for a short distance and then leaving it.

5:55 P.M. Eleven ants wandering on the upper surface and nine on the lower surface. Every once in a while an ant goes from one surface to the other on the trail.

5:58 P.M. Sixteen ants wandering on the upper surface.

January 27.-8:00 A.M. The trail which the ants are using this morning does not coincide exactly with the old trail. It goes over the edge of the disk at the same point, but at an intermediate point between the circumference and the stem it is about $1 / 2$ inch to the side of the old trail. The disk has been removed 6 hours and Io minutes.

January 26.-6:00 P.M. I remove disk B.

Jamuary 27.-8:05 A.M. I replace disk B. The ants can still follow the trail, but it is evidently very indistinct to them. The first ants from either direction start out over the trail, very slowly however. 'They move a little way, stop, go on, turn around and go back to the stem and then wander about over the disk, apparently searching for a more distinct trail. Nearly all those that go over the edge of the disk, however, do so at the point where the old trail goes over. The ants follow the trail quite closely on the under side, although they move very slowly. I think the ants feel less like wandering 
about on the lower surface because of their inverted position, and they therefore "smell" their way much more carefully.

8:45 A.M. The ants are still wandering about on the upper surface of the disk. A number of them cross and recross the trail many times without seeming to notice it. On the lower side they are following the trail closely.

9:30 A.M. The ants are not yet following the trail on the upper side.

IO:IO A.M. The ants still wandering on the upper side, but occasionally one follows the trail. 'T'rail closely followed on the lower side.

II :05 A.M. More ants are following the trail, but they still wander about considerably on the upper surface. faces.

I :55 A.M. The ants are now following the trail on both sur-

February 2.-4:00 P.M. The last few days I have been using new disks, $\mathrm{C}$ and $\mathrm{D}$. I remove the top disk, D, and replace it with a fresh one, $\mathrm{E}$.

February 3.-8:00 A.M. I remove disk C and replace disk D. $\mathrm{D}$ has been removed I 6 hours. The ants can still distinguish the trail and some of them follow it, sometimes turning and retracing their steps, sometimes wandering out to the side and then back, a few of them, however, following it with very little or no hesitation.

9:30 A.M. The ants are following the trail as though nothing had happened.

3 :Oo P.M. I remove disk E.

February 4.-8:00 A.M. I replace disk C. It has been removed 24 hours. 'The ants begin to follow the trail with about the same readiness that they did the one yesterday that was removed for $\mathrm{I} 6$ hours. There seems to be even less confusion, but this is probably due to the fact that not nearly so many ants are passing this morning.

2:30 P.M. I remove disk D.

5:30 P.M. I replace disk $\mathrm{E}$. It has been removed $26 \mathrm{I} / 2$ hours. I can not make out positively whether any of the ants recognize the trail or not. I had placed a piece of fresh meat on the bottle in the afternoon, and a much larger number of ants are passing than usual. A great many ants are scattered over the surface of the disk. Some of them seem to follow the trail for a little way and then lose it, but I can not be sure that they do not just happen to follow the trail for a short distance. More of the ants pass from one surface of the disk to the other at or very near where the trail goes over the edge than at any other place. I watch them until 6:00 p. m. but can not tell whether they are going to follow the trail or not. 
8:oo P.M. The ants are not ising the old trail. They are still wandering a great deal, but seem to be following a trail at an angle of about 15 degrees to the right of the old one and 75 degrees to the left of the trail on the lower disk.

8:45 P.M. The new trail is now fairly definite.

February 9.-2:00 P.M. I remove disk E.

February Io.-3:I5 P.M. I remove disk $\mathrm{C}$ and replace disk $\mathrm{E}$. Disk $\mathrm{E}$ has been removed 25 hours and $\mathrm{I} 5$ minutes. Most of the ants do not recognize the trail, but a few of them seem to do so.

3:30 P.M. A great many ants are scattered over the disk. Now and then an ant seems to recognize the trail and follows it for a short distance, five or six of them following it over both surfaces.

4:Oo P.M. Ants still wandering about on the disk, but occasionally one seems to follow the trail.

4:40 P.M. The ants are now following the trail with very little wandering.

February II. $-5: 30$ P.M. I replace disk C. It has been removed 26 hours and I 5 minutes. I can not see that the first ants that reach the disk recognize the trail. I watch them for Io minutes; most of them do not follow the trail but wander about on both surfaces. A few of them, on the lower surface, seem to recognize the trail and several pass over the edge at or near the place where the trail passes over.

February I2.-IO:O0 A.M. The ants are following the old trail. February I6.-I :45 P.M. I remove disk C.

February $17 .-5: 00$ P.M. I replace disk C. It has been removed 27 hours and I 5 minutes. The first ants that reach the disk do not seem to recognize any trail. Some start back to the nest or the food, and some wander about on the disk.

5:IO P.M. I notice two ants follow the trail on the lower surface, go over the edge, and then wander about on the upper surface. A great many ants are wandering about on the upper surface of each disk.

5:20 P.M. Now and then an ant follows the trail on the lower surface and loses it on the upper surface.

February $18 .-8: 00$ A.M. The ants have formed a new trail, about 65 degrees to the left of the old one and about i 5 degrees to the right of the one on the lower disk.

The above experiments show that a trail formed over cardboard by $M$. pharaonis may be recognized after it has ceased to be used for 26 hours and I 5 minutes. No doubt factors such as the material over 
which the trail is formed, atmospheric conditions, etc., would cause a difference in the length of time a trail could remain unused by the ants and still be recognized.

An idea of the number of ants passing over the trail in these experiments may be gained from the following counts taken at various times.

Jamuary 22.-Between II :45 and I I :50, sixty-one ants passed a certain point on the trail, twenty-five going to the food and thirty-six to the nest.

January 25.-Between 3:00 and 3:05, ninety-seven ants passed a certain point, sixty-two going to the food and thirty-five to the nest.

January 26.-Between 9:45 and 9:50, seventy-eight ants passed a certain point, thirty-nine going each way.

February 2.-Between I I :32 and I I :37, seventy-four ants passed a certain point, thirty-six going to the food and thirty-eight to the nest.

\section{EXPERIMENT NO. 5}

Can ants recognize which direction on the trail leads to the nest?

Of the seven ants (Experiment 3) placed on the trail from another room of the building, three followed it to the food and the other four to the nest. There is here the possibility that three ants sought the food purposely and that four purposely followed the trail to the nest.

Jannary 28.-2:45 P.M. With a camel's hair brush I pick up from the edge of the jar upon which the apparatus is resting today, an ant, No. I, going to the food, and place it on top of the lower disk near the trail. It crosses the trail without seeming to recognize it, goes around the disk once, crosses the trail again, goes half-ivay around the disk again, and then reaches the stem, where it takes the trail and goes to the food, which it reaches at $2: 50$.

2:55 P.M. I take No. 2 from the top disk, going towards the nest, and place it on the lower disk near the trail. It recognizes the trail and after a little hesitation starts towards the food. When it reaches the stem it turns and follows the trail back to the nest.

3:07 P. M. I take No. 3 from the edge of the jar, going to the food, and place it on the lower disk near the trail. It crosses the trail, wanders about for a short time, then strikes the trail and starts to follow it to the nest. It goes over the edge of the disk to the stem, then on past the stem and seems to be lost for a short time, then back to the stem and down it to the edge of the base. There it 
turns and retraces its steps over the base as far as the stem, then turns again and continues toward the nest.

3:32 P.M. I take No. 4 just as it reaches the top disk, coming from the food, and place it on the lower disk near the trail. It starts on the trail toward the nest, crosses to the under side of the disk, then turns and comes again to the upper side, wanders about for a while near the edge, goes to the lower side, back to the upper, then on the trail again to the lower side, follows the trail to the edge of the base, turns and goes back about half an inch, then turns again and continues towards the nest.

3:50 P.M. I take No. 5 from the edge of the jar, going to the food, and place it on the lower disk near the trail. It crosses the trail three times. The fourth time it comes to the trail it follows it to the food, which it reaches at $3: 55$.

4.07 P.M. I take No. 6 just as it reaches the top disk, coming from the food, and place on top of the lower disk near the trail. It follows the trail at once to the nest.

It will be noticed that the three ants taken as they were coming from the food, Nos. 2, 4, and 6, finally followed the trail to the nest, and that of the three taken as they were coming from the nest, one, No. 3, goes back to the nest, while the other two, Nos. I and 5, continue to follow the trail to the food. This is, of course, insufficient data to base any conclusions whatever upon, so, later on, I isolated two groups of ants on islands in a pan of water for several days, providing one group with plenty of food and keeping the other without food. I then transferred them, one at a time, to the new trai] which I had caused to be formed in the meantime. The results, however, were not very satisfactory, so I shall not give them in detail. It was impossible for an ant to follow the trail very far without meeting others, and there was often a tendency for the ant placed upon the trail to turn about and follow others which it met, although sometimes it merely stroked antenne with them and went ahead.

An experiment along this same line consisted in removing one of the disks and replacing it with the lower side uppermost, thus reversing the direction of the trails on both surfaces. This caused some confusion, but I think no more than was caused by merely removing the disk and replacing it in the same position. Although the above experiments are not at all conclusive, yet it seemed to me that the ants merely recognized the trail as such, and could not tell which direction on the trail led to the nest. I did not find in the behavior of these ants any support for Bethe's "Polarized 'Trail" theory. (Bethe, 1902.) 


\section{ADDITIONAL, NOTES}

Whenever I caused a new trail to be formed, or placed on a new disk, I always watched carefully for any signs of communication when the first ants from the food met those from the nest. One would think that these conditions would be ideal for any power of communication on the part of the ants to manifest itself, since the ants on one side knew the way back to the nest and were searching for the food, while those on the other side knew the way to the food and were trying to get back to the nest. Yet I failed to observe anything in the behavior of the ants which I could interpret as communication. To be sure the ants meeting under the above circumstances always stopped and stroked antennæ, but when they separated each continued to wander as aimlessly as before, and the gap in the trail was finally bridged by the ants from one side accidentally striking the trail on the other. I do not, of course, mean to say that communication among ants does not exist. In fact, stridulation, gestures, postures, etc., on the part of the ants undoubtedly do represent some form of communication, as has been shown by Wheeler, Forel, and Wasmann. I do mean to say that with this particular species and under these particular conditions I failed to observe anything, which, from its effect upon the behavior of the ants, I could interpret as communication.

As a rule the queens of $M$. pharaonis do not leave the nest to feed, but quite often when I placed out some food particularly attractive to the ants, such as a piece of fresh beef, especially if the room was quite warm, a number of queens would follow the trail out to it. Ordinarily, however, they did not feed, and I think they were only induced to come out by the fact that a very large number of workers was passing in and out. During the winter I captured fifteen dealated queens from this one colony.

The queens follow a trail just as the workers do, and without having been over it before. One rather amusing illustration of this was exhibited when I placed a queen, previously isolated, upon a disk having a newly formed trail on it. I first removed the disk from the apparatus and held it in my hands during the experiment. The queen wandered about until she struck the trail, which she at once began to follow. She followed it over the edge to the lower surface, where she continued until she reached the hole in the center of the disk through which the rod had passed. After a little hesitation she crawled through the hole to the upper surface, coming out on the trail above, and thus making it continuous. She continued following 
the trail, going over the edge to the lower surface, back through the hole in the center, until she had completed the round more than a dozen times. After that she seemed to realize that she was not getting anywhere and began to wander about.

\section{CONCLUSIONS}

I. A trail once formed by Monomorium pharaonis is followed regardless of any change made in its direction.

2. Change in the direction from which the light comes does not influence this species in following its trail.

3. Ants of this species can recognize a trail laid down by other individuals of the same or of a different colony.

4. Monomorium pharaonis can still recognize a trail sufficiently well to follow it, after it has ceased to be 1 sed for at least 26 hours and $I_{5}$ minutes.

5. The behavior of ants of this species when placed upon the trail seems to indicate that they do not recognize which direction leads to the nest.

I do not, of course, attempt to apply these conclusions to all ants, for a study of the literature upon ants, or, better still, a study of the various species of ants themselves, will soon convince one that there is probably as much diversity in the habits of different species of ants as there is in the habits of different species of mammals or of birds. It is probable, however, that they may apply more or less closely to those species of ants which have very small eyes and travel in regular files. 


\title{
EMBRYOLOGICAL STUDIES
}

\author{
Studies on THE Embryology of Camponotus herculeanus \\ var. ferrugineus Fabr. AND Myrmica scabrinodis \\ var. sabuleti Meinert
}

\section{METHODS}

The eggs for the studies on the first species were obtained from two large colonies of Camponotus herculeanus var. ferrugineus which I kept through the winter in large Fielde nests (Fielde, I904). The temperature of the laboratory in which they were kept was about $70 \mathrm{~F}$., and remained practically constant day and night. Each colony contained one queen. The ants were fed on dead insects, insect larvæ, sugar water, pieces of lean meat, and the yolk of egg. The queens began laying in December and January, and laid during the rest of the winter. Sometimes I allowed the eggs to accumulate in the nest until the first ones began to hatch and then killed the entire bunch, thus getting all stages. The egg periods varied, but averaged between twenty-five and thirty days. Very often by the time the first eggs began to hatch there were from one hundred to two hundred eggs in the nest. Sometimes I removed the queen and a few workers to another nest and removed the eggs each day, placing them with other workers, in order to estimate the time. I found it a very difficult matter to get the later egg-stages in this way because of the fact that the workers ate many of the eggs; but it was necessary to have the eggs with workers or with a queen in order to prevent their being attacked by fungi. In order to remove the eggs or the queen, the entire colony was first stupefied with cold.

The eggs were killed and fixed in a saturated solution of mercuric chloride in $35 \%$ alcohol to which had been added $2 \%$ of glacial acetic acid. The solution was used at a temperature just below the boiling point. The eggs were then transferred to $70 \%$ alcohol, in which they were left until the following day, or later. While in $70 \%$ alcohol the embryos were dissected out from the membranes surrounding them by means of fine dissecting needles. This could be accomplished, after a week or two of practice, with little difficulty. The embryos were then stained in toto in Grenacher's alcoholic boraxcarmine, Delafield's or Ehrlich's hæmatoxylin, or orange G, and then, after decolorizing, carried up through the various grades of alcohol 
to some clearing agent. I always over-stained the material and then decolorized in acid alcohol. For the study of the entire embryo a rather faint stain is much the better; but for embryos that are to be sectioned, a heavier stain is desirable.

For clearing I used xylol, cedar oil, and clove oil. The two latter I found cleared a little better than xylol, and were more desirable also because of the fact that they do not evaporate so rapidly. I kept the embryos in the clearing agent in a watch crystal; but for drawing and for the study of any particular embryo, I removed it to a microscope slide upon which I had built up a ring of cerasine to such a height that the depth of the cell formed was just a little greater than the thickness of the embryo. Then by moving the cover-glass the embryo could be made to assume any desired position. An embryo can be kept in such a cell for weeks at a time. For the study of certain structures I found it very desirable to cut the embryo in two and to remove all the enclosed yolk. The spiracular openings, for instance, I could not make out until I had resorted to this method.

For sectioning the earlier stages I did not remove the egg membranes. I found that by piercing the chorion and allowing the egg to remain in melted paraffine for from eight to twelve hours it sectioned very well. 'These eggs were all stained in toto in Ehrlich's hrmatoxylin and then counterstained on the slide with orange G, by the use of a saturated solution in $95 \%$ alcohol. I found that by using this method I did not over-stain with the hæmatoxylin; that I got a much better stain than by staining on the slide; avoided the necessity of running the slides through the different grades of alcohol, and hence much danger of losing sections by washing them off; and saved a great deal of time. The orange G differentiated the yolk from the superficial layer of protoplasm or from the germ layers. The sections were cut with a Minot's rotary microtome and mounted with Meyer's albumen fixative. The drawings were made in outline with an Abbé camera lucida.

\section{THE EGG}

The egg of $C$. formgineus may be described as somewhat Paramoecium-shaped, with a blunt, narrow anterior end, and with its greatest transverse diameter about one third the distance forward from the posterior end. The length of the egg is about $\mathrm{I} .4 \mathrm{~mm}$. and the transverse diameter is about $.5 \mathrm{~mm}$. When the egg is laid the posterior end makes its appearance first. 
There are two external membranes, the chorion and the vitelline membrane. The chorion is made up of two membranes: an outer, or exochorion, and an inner, or endochorion. It is difficult to distinguish these two layers in sections, but sometimes when the eggs are removed from the fixing agent to $70 \%$ alcohol the inner layer separates from the outer one in bubble-like areas, and the two can then be further separated by needles. The vitelline membrane is somewhat thinner and much more delicate than the chorion. The former stains more heavily with hæmatoxylin, while the latter stains more heavily with orange G. I was not able to distinguish any structure that I could identify positively as a micropyle. Ganin ( 1869 ) states that there is a single micropyle at the posterior end of the egg. Blochmann (I884) states that a micropyle occurs at the animal pole or upper end of the egg. It is probable that he means by "animal pole" the posterior end of the egg, since he says that he found what he took to be the egg nucleus and the sperm nucleus at that end of the almost ripe ovarian egg. In the freshly laid egg the nuclei always occur at the posterior end.

If a freshly laid egg be sectioned longitudinally, it will be found to present the appearance shown in Plate I, Fig. I. On the outside is the chorion, which stains rather deeply with orange $\mathrm{G}$; and inside the chorion, closely investing the protoplasm, is the vitelline membrane, which takes the hæmatoxylin stain. On the inside of the vitelline membrane is a comparatively thick layer of peripheral protoplasm, much thicker at the posterior than at the anterior end or at the sides. The part of this layer in the posterior one-third of the egg is noticeably different from that of the anterior two-thirds, that at the anterior end being much more vacuolated, with a tendency toward network formation, while that at the posterior end is almost devoid of vacuoles. Numerous small yolk granules are seen embedded in this protoplasmic layer, especially at the posterior end. In many places the small granules are found fitting into small pocket-like depressions. In other places the outer edges of these depressions, meeting, enclose the granules in vacuoles. This indicates the manner in which the yolk granules probably become embedded in the peripheral layer of protoplasm.

Another respect in which the protoplasmic layer at the posterior end differs from that at the anterior end and at the sides is in the presence of an immense number of minute rod-like bodies which almost completely fill the protoplasm at that end of the egg and stain readily with hæmatoxylin. Blochmann (' 84, pp. 245-246) mentions finding these bodies in the ovarian eggs of Camponotus ligniperdis 
and Formica fusca, but says that they disappear with the formation of the yolk in the egg. He found them later (' 87 and '92) in certain other insects, and similar bodies have since been found by Forbes ( 1892 ) in the crecal glands of varions Hetcroptera, and identified by him as bacteria, and by Wheeler ('89, p. 306) in the egg of Blatta germanica. Recently they have been proved to be bacteria by Mercier ('o7), who grew them in cultures. Those I found in C. herculeamus stain deeply with eosin and with methylene blue but do not take the Gram stain. So far as I know this is the first time these bacteria have been seen in ants' eggs in this country.

The peripheral layer of protoplasm at its inner edges passes out into what appears in sections as a delicate network of protoplasm which extends through the entire egg. This delicate network shows very clearly because of the fact that the protoplasm stains more strongly with hæmatoxylin while the yolk granules stain more strongly with orange $\mathrm{G}$. Both protoplasm and yolk will take either stain, but the yolk stains much more readily with orange $\mathrm{G}$, while the protoplasm stains much more readily with hæmatoxylin, thus producing a very good differentiation. Near the posterior end of the egg, and to a less extent near the anterior end, this network leaves many large vacuoles between which occur yolk granules. Near the center of the egg the yolk granules are massed to such an extent that there are very few or no vacuoles. These yolk granules vary in size, and also somewhat in shape, but approach a globular form, and are very finely granular. They range in size from a diameter of about $.005 \mathrm{~mm}$. to a diameter of about $.027 \mathrm{~mm}$., with an average diameter of about .oi $8 \mathrm{~mm}$.

In the peripheral layer of protoplasm at the posterior end of a freshly laid egg, or of one at a somewhat later stage (one to thirteen hours), is found a very large, much vacuolated, heavily staining nucleus (Figures I and 2). In addition to this, there is found situated very near the large one, in some of the eggs, a much smaller nucleus (Figures I and 3), having the same appearance as the large one except that it is generally denser, that is, less vacuolated. In one of my slides the two nuclei were just touching each other. In sections of several somewhat later stages, still more nuclei of exactly the same appearance were found. These nuclei all had the same appearance structurally. I did not see in those I examined any appearance of karyokinetic figures. Of two eggs killed just after being laid, one contained but the one large nucleus, the other contained the large nucleus and a small one. Of three eggs one hour old, one had only the one large nucleus, one had the large one and one small 
one, and the other had the one large nucleus and two small ones. One egg four liours old showed but the one large nucleus. Of five eggs from one to four hours old, one had two nuclei, the large one and one small one; each of the other four had only the large nucleus. One egg, from one to twelve hours old, had but the one large nucleus.

In an egg killed eight hours after laying, I found three nuclei, each about one third as large as the large ones mentioned above, and two smaller ones, all having the same characteristic vacuolated appearance. All five were in the peripheral layer of protoplasm near the posterior end of the egg. In another egg eight hours old there was but the one large nucleus at the posterior end of the egg; but in addition to this, in the midst of the yolk at about one-third the distance from the anterior end, appeared a few small irregular stellate nucleated masses of protoplasm, having exactly the same appearance as the ones that appear successively more numerous in somewhat later stages. In an egg eleven hours old, there was but the one large nucleus at the posterior end, and near the anterior end there were a few small irregular nucleated masses of protoplasm. In addition to these, scattered throughout the yolk in the posterior half of the egg, were a number of small stellate masses of protoplasm, most of which had exactly the same appearance as those at the anterior end except for the fact that I could not see that they were nucleated. Some of them looked very much as though they were detached fragments of the large nucleus, having the same vacuolated appearance. The yolk is now changing its appearance, becoming liquefied, the yolk granules breaking down and the vacuoles increasing in size and number. In a thirteen-hour stage I found only the one large nucleus. In an egg twenty hours old I found one nucleus, very large and very irregular (Figure 4), at the posterior end in the usual position of the large nucleus. In addition to this, in the yolk occur a number of small, rather deeply staining, vacuolated masses that have the same appearance structurally as the large nucleus. They appear either to be made up entirely of cytoplasm or entirely of karyoplasm, that is, there is no part more deeply staining than the rest to indicate that they are nucleated masses of protoplasm. The large nucleus was $.09 \mathrm{~mm}$. across, and the largest of the small masses was .025 $\mathrm{mm}$. in diameter. In the anterior half there are scattered throughout the yolk near the center of the egg, a number (about twenty altogether) of stellate masses of protoplasm with small, globular, deeply-staining nuclei. These generally occur in pairs, indicating their origin by division. The conditions which are described above must be similar to those found by Weismann in Cynipidc. "According to Weismann, 
in Rhodites and Biorhiza aptera (Cynipide) the first cleavagenucleus divides at first into nuclei which shift apart in the direction of the longitudinal axis of the egg, and, according to their position, are known as the anterior and posterior "pole nuclei." While the anterior nucleus remains inactive for some time, the posterior, by a kind of budding (?), gives rise to numerous nuclei, which take part in the formation of the blastoderm. The anterior nucleus, on the contrary, after the completion of the blastoderm, is said to produce by division the nuclei of the so-called inner germ-cells or yolk-cells."* In the case of Camponotus, however, the anterior cells go to make up at least the greater part of the blastoderm.

In the next stage I have, (marked one day old,) the nucleated masses of protoplasm are beginning to arrange themselves in a regular layer in the yolk just a little distance in from the peripheral protoplasm (Figure 5). This layer is more regular and the nuclei are more numerous in the anterior than in the posterior half of the egg; furthermore, the nuclei lie nearer the periphery. There are still a great many nuclei scattered indiscriminately through the central portion of the yolk. Division seems to be going on much more rapidly in the anterior half, and many karyokinetic figures can be seen, sometimes six or eight in the same section.

In a stage a few hours later the nuclei at the anterior end have migrated outward until they form a loose layer in the peripheral protoplasm. Towards the posterior end the nuclei do not divide so rapidly and do not reach the peripheral protoplasm as soon as at the anterior end, so that a longitudinal section of this stage has the appearance shown in Plate II, Figure 6. Figure 7 shows a section through the peripheral layer of protoplasm at the anterior end parallel with the surface.

\section{FORMATION OF 'THE BLASTODERM}

By the time the nuclei have reached the periphery at the posterior end of the egg the layer of protoplasm in the anterior half has become divided by deep fissures, running in from the outside, into columnar cells, each cell containing one nucleus. The nucleus has in each case migrated outward to the extreme distal end of the cell. These cells are not formed, however, over the entire surface. 'They form a cap over the anterior end, and extend on the ventral surface, backward, about half-way to the posterior end. The dorsal half of

*Quoted from Korschelt aud Heider (99, p. 264). 
the egg is still uncovered with cells. The nuclei here lie embedded in the peripheral protoplasm, which has become much thinner. There are still many nucleated stellate cells scattered throughout the yolk. This stage, which represents conditions at the beginning of the second day, is illustrated by Plate II, Figure 8.

During the second day (Pl. III, Fig. 9) cells are formed over the entire surface of the posterior half of the egg in the same way that they were formed over the ventral surface of the anterior half the first day. These cells differ from those at the anterior end in being much larger and broader. The protoplasm is mostly at the distal end of the cell, while the basal part contains an immense number of yolk granules. At this stage those cells at the posterior end contain also a very large number of the bacteria mentioned above. The nuclei in these cells lie in the distal ends, as do those of the anterior end, but they are not nearly so easily made out. On the ventral surface the cells of the posterior half meet those of the anterior half about half-way between the two poles to form a continuous layer. The transition from one type of cell to that of the other is not a gradual one but is rather abrupt. On the dorsal surface the layer of cells from the posterior end has grown forward about the same distance as on the ventral side, but the layer of cells from the anterior end has not grown backward to meet it, so there is still a small area on the dorsal surface just back of the anterior end that is as yet not covered with cells. The protoplasmic layer has changed here until there is nothing but a thin membrane separating the yolk from the vitelline membrane (Fig. Io).

The cells that were described above as being formed the first day on the ventral surface of the anterior half have changed decidedly in appearance. They have become longer and more columnar and taper somewhat at the base. This layer of cells forms the beginning of the germ band. At their proximal ends they merge into the protoplasm which has formed a layer lying between the yolk and the cells. In the posterior half this layer almost disappears in the protoplasmic network; but in the anterior half it is much heavier and really forms a syncitium, since it contains quite a number of nuclei. This syncitium seems to act as a kind of "feeder" to the layer of cells, since it is the seat of rapid nucleus formation, nuclei appearing here in various stages of mitosis, and since the nuclei being formed here appear to migrate outward, drawing with them a part of the syncitial protoplasm, thus forming new cells. These migrating nuclei can be found at the distal ends of the cells just forming in this way, anywhere between the protoplasmic layer and the 
level of the distal ends of the mature cells. This view of the tunction of the syncitial layer is further supported by the fact that in two places in this layer there are longitudinal thickenings containing many more nuclei extending from the anterior end backward as far as the end of the germ band, and these thickenings occur near the lateral edge of the germ band, or where there is greater need for rapid cell-formation. Furthermore, a larger number of the cells of the germ layers are connected at their bases with the syncitial thickening than with any other equal area of the layer. This is shown by Figure Io, which represents a cross-section through the posterior part of the germ band at this stage, that is, just a little in front of the middle of the blastoderm. It will be noticed that there are large blastoderm cells on the dorsal side, showing that here this layer has grown farther forward on the dorsal side than the point on the ventral side where the blastoderm cells meet the posterior end of the germ band, which in this stage is about the middle of the egg. Figure II represents a transverse section of the same egg taken farther forward, through the region where there is still a small area on the dorsal side that is not as yet covered by the blastoderm cells; the dorsal side of the section is limited, consequently, by the thin protoplasmic layer mentioned above.

In Figtres 9, IO, and I I, most of the cells, both of the germ band and of the blastoderm outside the germ band, are seen to contain a very large number of yolk granules which have passed through the protoplasmic layer into the bases of the cells. The large cells of the blastoderm especially are distended with the yolk grantles, the amount of yolk in many cases being greater than the amount of protoplasm. At this stage many of the yolk granules have broken down, leaving a granular liquid mass. The stellate yolk cells have almost disappeared, only a few being found scattered throughout the yolk mass. At the posterior end of the section shown in Figure 9 may be seen a group of cells lying just inside the blastoderm which are smaller than the cells of the blastoderm. Also, in view of their later development, mention should here be made of certain cells in the posterior ventral part of the blastoderm which have become very greatly enlarged, and at their bases contain a large number of yolk granules. The protoplasm in these cells is denser than in those just at the end. One such cell is shown in Figure 9.

An examination of the section shown in Figure II, shows that the cells in the middle of the germ band at this point have taken on a different appearance from those at the sides. Instead of the narrow columnar cells with their nuclei out at their extreme distal ends 
which appear at the sides, and also in the middle a few sections back of this point, there are more or less globular cells having their nuclei near their centers. They are undergoing rapid division, as is shown by the fact that a large number are seen in various stages of mitosis. These cells, including about the middle one-third of the germ band, are seen to be sunk below the level of the columnar cells on either side, forming a broad shallow depression. This depression, which has been termed by some embryologists the middle plate, represents an invagination from which will arise the mesoderm. At this stage the middle plate occurs only near the anterior end.

In a stage a day later (three days old) the small area on the dorsal side that still remained uncovered by the blastoderm has become overgrown by the layer of cells, so that we now have the blastoderm and the germ band completely enclosing the yolk (Fig. 12). Sections through the egg at this stage show us that the cells of the blastoderm are not all alike. In the first place we have in the anterior half of the ventral surface, the germ band, the surface cells of which are columnar and stain deeply with hæmatoxylin (Fig. I2). Just posterior to the germ band comes a layer of large polygonal cells containing only a small amount of protoplasm in comparison with the large amount of yolk material within them. The protoplasm, which is rather dense, but does not stain so deeply as in the cells of the germ layer, is all together, while the yolk granules fill the rest of the cell. This layer extends almost to the posterior end, but just before that end is reached a few enormously enlarged cells occur which closely resemble those just described, but are conspicuous because of their great size. They appear to be multinucleate, although their nuclei do not show up very well, and to enter into close relationship with the posterior end of the inner protoplasmic layer. They contain a number of vacuoles, and, like the cells just described, they contain a very large amount of yolk material, and their rather dense protoplasm stains more lightly than that in the cells of the germ band. At the posterior end, and extending forward from these almost half the distance on the dorsal side, occurs a layer of rather large polygonal cells which contain only a few yolk granules. The protoplasm of these cells is less dense than that of the cells just described, but it takes a deeper stain, and hence these cells are very easily distinguished from the others. About half-way between the anterior and posterior ends, these cells give way to cells of the same kind as those which occur just posterior to the germ band on the ventral surfaces. These cells extend forward on the dorsal surface to meet the germ band at the anterior end of the blastoderm. 
At the anterior end of the germ band, a transverse depression, or invagination, occurs, beneath the floor of which there has developed a large cell-mass composed of more or less circular cells having deeply staining nuclei. These cells represent a further development of the cells mentioned as occurring in the two-day stage below the middle plate. The middle plate at this stage, with its accompanying cells beneath, extends back a little farther than in the two-day stage.

Just a little distance in front of the transverse depression, or invagination, the large cells which cover the anterior half of the dorsal part and extend to the anterior end of the blastoderm give way to a one-celled layer of somewhat flattened loosely-connected cells, which resemble the cells of the germ band in their structure and in the manner in which they stain. This layer, which at this stage extends backward only a very little way, not yet bridging the invagination, represents the beginning of the serosa. At the posterior end of the germ band also, there is a slight transverse groove, from the posterior border of which a few cells extend forward over the posterior end of the germ band. These cells, however, are not different in character from those just posterior to them, that is, they have not changed their shape so as to form a layer of flattened cells similar to the one extending backward from the anterior end. At both the anterior and posterior ends the lateral edges of the germ band are sinking slightly below the level of the other cells so that both grooves are slightly crescentic, the horns of the anterior one extending backward, and these of the posterior one extending forward.

The inner protoplasmic layer, which lies between the cells and the yolk mass, is very greatly thickened at the anterior end, where the greatest cell growth is taking place. The posterior end of this layer seems to have contracted somewhat, ending bluntly, and leaving a space between it and the posterior end of the blastoderm. Near the dorsal side the group of small cells, mentioned in the description of the two-day stage as lying just inside the posterior cells of the blastoderm, are seen to be applied to this blunt, posterior end of the inner protoplasmic layer, although they still retain a loose connection with the surface cells. The bacteria mentioned above can still be seen in the posterior cells. There are still a very few cells scattered throughout the yolk mass.

In the sections I have representing the four-day stage there are few further changes of importance. The serosa has grown farther backward over the germ band, extending about half its length. Its anterior attachment has begun to retreat somewhat over the antero- 
dorsal part of the blastoderm toward the posterior end, so that the anterior end of the blastoderm is now completely enclosed by the serosa. This retreating of the attachment of the amnion apparently takes place by a kind of progressive delamination from the blastoderm cells successively farther back. The anterior end of the germ band has retreated somewhat and the anterior cell-mass has increased in size. The middle groove and the middle plate have grown farther backward but have not reached the posterior end of the germ band, while at the anterior end the surface is again even, the middle groove having grown over. The transverse depression at the posterior end of the germ band has become somewhat deeper, but the blastoderm cells at the posterior edge of this depression have grown forward but little if any farther than in the last stage described.

In a stage five days old (Pl. IV, Fig. I5), the serosa has grown backward on all sides almost to the posterior end of the blastoderm, enclosing the large cells of the blastoderm and the germ band. At the posterior end of the germ band the serosa did not unite with the forward-projecting cells from the posterior end of the transverse groove, but continued to grow on backward, enclosing those cells with the posterior end of the germ band.

At the position of the transverse groove mentioned in preceding stages, the germ band dips downward and backward diagonally and then continues to grow toward the posterior end, following the thin layer of peripheral protoplasm. At this stage the backward growth from the lower end of the incline has proceeded only for the length of a few cells. From that point backward toward the posterior end of the blastoderm the layer of inner protoplasm, which although very thin is easily distinguishable, rises again toward the surface, leaving a very broad depression, in which lie a mass of large blastoderm cells covered by the serosa.

At the anterior end the germ band turns upward and then backward again on the dorsal side, and since the dorsal and ventral parts are now connected by a layer of cells, this gives to the anterior end of the germ band the appearance of a closed tube with the lumen opening backwards. The layer of thin epithelial cells forming the dorsal surface of this tube extends backward at this stage, as a delicate layer, to about the level of the transverse groove near the posterior end of the germ band on the ventral side. From this point the wall of the tube, which widens somewhat here, extends backward as the inner protoplasmic layer to the posterior end of the blastoderm, where, with the same layer from the sides and the ventral surface, it forms the other closed end of the tube. Between the antero-dorsal 
surface of this tube and the serosa lies a mass of cells in an irregular layer, of the same nature as those lying in the hollow on the ventral surface. The axis of the rounded, tube-like, anterior portion of the germ band does not coincide with the longitudinal axis of the entire egg, but is anteriorly inclined towards the ventral surface. The hollows on the dorsal and ventral surfaces give to the germ band and the inner protoplasmic layer a somewhat slipper-shaped appearance in longitudinal vertical sections, the heel being formed by the germ band and the toe by the inner layer of peripheral protoplasm, the longitudinal axis of the slipper lying diagonal to the longitudinal axis of the egg. Encircling the toe of the slipper and extending forward on the dorsal surface about half the length of the blastoderm are the rather deeply-staining cells mentioned as occurring in this position in the three-day stage, but the layer has pushed forward farther on the dorsal side at this stage. Most of these cells contain the bacteria mentioned above. At the anterior end of this layer on the ventral surface occur the large vacuolated multinucleate cells described above. The group of cells originating at the anterior end of the ventral groove has increased greatly in size so that the anterior end of the germ band now appears as a solid mass of cells. The ventral groove and the cells of the middle plate have just about reached the posterior end of the germ band.

At the age of six days the germ band has grown backward on the ventral side along the inner layer of peripheral protoplasm to the most posterior place occupied by that layer in the region of the middle of the egg near the posterior end (Fig. I6). It has grown back as a layer several cells in thickness in the median line, thinning out to a delicate one-celled layer laterally. Over the anterior half this layer is continuous with the delicate one-celled layer extending backward from the antero-dorsal part of the germ band, forming here a dorsal closure of the embryo. This dorsal closure has not yet been effected over the posterior part. The layer of inner peripheral protoplasm now contains a great many more nuclei, so that it forms a loose nucleated layer extending over the entire dorsal area and lying just inside the delicate one-celled layer which is continuous with the edges of the germ band.

At the very posterior end of the germ band a significant change is beginning at this stage. The germ band now extends back to the point where the peculiar, large, multinucleate cells and the large heavily-staining cells, mentioned as occurring at the posterior and the postero-dorsal part of the blastoderm, begin. At this point the germ band forms a knot-like thickening, and from this thickening 
there extend several finger-like processes composed of the small germband type of cells. These finger-like processes work themselves in between the large blastoderm cells, tending to enclose them in meshes. The significance of this process will be seen in later stages.

The embryo, as it may now be called, has shortened somewhat in length and at the same time has increased in circumference, so that the large blastoderm cells mentioned in the five-day stage as occurring in hollows on the dorsal and ventral sides of the germ band have been crowded out of these positions, those on the dorsal side being forced into the anterior end of the egg, and those on the ventral side now occupying the postero-ventral part of the egg. These cells contain a great deal of yolk and are evidently absorbed as food, since they gradually disappear in later stages. The ventral side of the embryo now lies next to the vitelline membrane, and the dorsal side is separated from the vitelline membrane by only the single layer of the large heavily-staining blastoderm cells, which now extend well towards the anterior end of the embryo, and which at the posterior end are beginning to be enclosed by the finger-like processes from the posterior end of the embryo.

In an eight-days stage (Fig. I7) the small cells which originally grew out as finger-like processes from the posterior end of the germ band have increased in number to such an extent that they now enclose all the large heavily-staining blastoderm cells mentioned above and the large multinucleate cells in a perfect meshwork, extending as far forward dorsally and laterally as the large cells extend, that is, almost to the anterior end of the embryo. At the posterior end these large cells are in a group which becomes thinner as it extends forward, until near the anterior end it becomes a layer one-celled in thickness. This group ends posteriorly with the large multinucleate cells. The cells forming the network are very small, but are easily detected by the presence of the deeply-staining nuclei. At the posterior end of the embryo where the germ band broke up into the fingerlike processes consisting of the small cells, the outermost of these processes, which is now a very thin, delicate membrane, extends backward over the large multinucleate cells, and enclosing the group of large heavily-staining cells continues forward to meet the thin layer extending backward on the dorsal side of the embryo, thus forming the dorsal closure, and thus including, as a part of the embryo, the large cells which originated in an entirely different part of the blastoderm from that which formed the original germ band (Pl. III, Fig. 9). The inner layer of peripheral protoplasm lies just beneath this network, thus enclosing it between two membranes. This inner layer 
has, scattered through it, very large and heavily-staining nuclei. One of these nuclei is shown in the figure situated at the anterior end and another at the posterior end, in very noticeable thickenings of the layer. The nuclei of the serosa have increased greatly in size and are now very conspicuots, lying just beneath the vitelline membrane.

The serosa is the only embryonic membrane that develops in the case of Camponotus to enclose the embryo entirely. This develops, as has been seen, by a backward growth as a single layer from the anterior border of the cephalic groove. At the posterior end of the germ band it does not unite with the posterior edge of the caudal groove, but grows on backward to enclose the rest of the blastoderm. This differs from the typical method of formation of embryonic membranes in two ways: (I) the entire membrane is formed by a growth from the cephalic fold, the caudal fold being rudimentary; (2) the growth occurs as a single and not as a double layer. There is, therefore, no amnion formed over the ventral surface of the embryo. The dorsal closure, however, has been effected, as has been described, by a delicate one-celled layer which is continuous with the edges of the germ band. This layer is similar in structure to the serosa. It grows out from the edges of the germ band, spreads dorsally, and closes over to form the dorsal body-wall of the embryo; hence it is to be regarded as the amnion.

Graber has shown ('88, Pp. I44-I46) that there are two embryonic membranes in Polistes gallica, Formica rufa, and Hylotoma berberidis. He says that the inner layer becomes closely applied to the germ band and is indistinguishable from the latter. In Camponotus I have been unable to find more than the one layer on the ventral side of the embryo. Carrière ('97, pp. 396) found but the one layer in Polistes gallica and Chalicodoma muraria, and Bütschli (I870) found but one in Apis. Ganin, who studied the development of several species of Formica and Myrmica, also says that there is but one embryonic layer.

The ventral part of the embryo, which is in the position of the original germ band, is now much narrower than the original germband and is in the form of a narrow ridge-like thickening along the median ventral line, widening out at the anterior, and, to a less extent, at the posterior end. Figure I8, Plate V, represents a crosssection of this stage showing the ridge-like thickening on the ventral side, and the large cells forming a layer extending about half-way around on the ventral side. The anterior widening shows the fundaments of appendages and of the stomodral invagination, but the proctodæal invagination does not appear until several days later. 
In an embryo ten days old the ventral thickening widens somewhat and the large dorsal cells have pushed farther around towards the ventral side. This process continues in succeeding stages, and in a cross-section of an embryo at the age of fourteen days we have the appearance shown in Figure I9. Here the ventral thickening has become wider and somewhat thinner and is composed of two layers: an outer, compact ectodermal layer; and an inner, somewhat looser layer of mesodermal cells. The large cells from the dorsal side have grown around a little farther toward the ventral side. These cells, together with the small cells which form a network among them, form a layer which is beginning to separate slightly from the thin ectoderm dorsally and laterally, leaving a small space occupied by scattered cells. The invagination of the proctodxum has not yet developed at this stage.

In a somewhat later stage, represented by Figure 20, (the exact age of these later stages can not be given,) the ventral thickening has widened somewhat, and in the middle of this thickening there are two longitudinal elevations, inside of which we see the beginnings of the nerve cord. These appear in cross-section as two circular areas of cells overgrown with the ectoderm. The layer of mesoderm cells which we found lying just below the ectodermal thickening in the fourteen-day stage has here split into two parts, one part lying on each side of the developing nerve cord.

The layer of large cells which has been growing around from the dorsal side has now reached the median ventral line, and the two edges unite to form a circular layer. 'The ultimate fate of these cells is now evident. They, together with the network of small cells which grew out from the posterior end of the germ band, and with the scattered cells of the inner layer of peripheral protoplasm, have formed the mesenteron. These cells which were enclosed in the network and were originally very large, are now much smaller, and there is no longer a clear distinction between the various kinds of cells which went to make up the layer. The mesenteron has now completely separated from the surface ectoderm, leaving a well-developed body cavity.

The mesenteron ends blindly at both ends. Its shape may be seen from Figures 22 and 24. Its wall is thick, appearing in sections as a protoplasmic network enclosing the cells. This network is especially noticeable on the inner border.

By this time, appendages have been formed and the invaginations of the stomodrum and proctodæum are well developed. The development of the appendages and the further development of the 
alimentary canal and of the nervous system will be given on the following pages.

THE DEVELOPMENT OF THE EXTERNAL FORM

Figure 2I, Plate V, represents an embryo about twelve to fourteen days old. The embryo occupies a position somewhat nearer the posterior than the anterior end of the egg, with a mass of large, faintly-staining cells at each end. The serosa encloses these cells with the embryo. The ventral thickening appears as a ridge along the median ventral line, curving around at each end in the form of a-large letter C. At the anterior end there is a slight widening of this ridge which indicates the beginnings of the procephalic lobes. At the posterior end the thickening passes insensibly into the darker posterior dorsal portion of the embryo. This is due to the fact, as we have noticed in the sections, that the posterior end of the original germ-band breaks up into finger-like masses of small cells which form a network around the large heavily-staining cells of the posterior end of the blastoderm. A very slight indication of segmentation has already made its appearance, due to the beginning of the formation of the ganglia of the ventral nerve-chain, the thickenings of which may be seen in lightly stained embryos. Sections of this stage show that the invagination of the stomodrum has just begun, but there is no indication of it as one looks at the entire embryo. The invagination of the proctodæum has not yet begun.

Figures 22 and 25 represent a stage in which the layer of cells from the inner posterior dorsal part of the embryo has grown around to the ventral side along its entire length, thus completing the mesenteron, which now has the appearance of a pear-shaped sac, closed at both ends, the small end being the anterior one. This pear-shaped sac enclosing the yolk almost fills the embryo, though a small space is noticeable between it and the outer layer or ectoderm, this space representing the body cavity. At the anterior end of the embryo there is a well-developed, thick-walled, backward-projecting, U-shaped invagination of the outer ectoderm which represents the stomodrum. The posterior end of the stomodxum almost reaches the anterior end of the mesenteron. The invagination of the proctodiatm is also well-developed at this stage. At the anterior end of the embryo at this stage the appendages are already well formed. Just in front of the stomodretm is a median evagination of the ectoderm projecting anteriorly and dorsally, which when viewed from the side appears as a pear-shaped body, but when viewed from a postero- 
dorsal direction appears as a narrow oblong with its greatest length extending transversely to the long axis of the embryo. This is the fundament of the labrum. On each side of the labrum is a wide lobe-like thickening of the ectoderm, the two constituting the procephalic lobes, and on each side of these is a small knob-like thickening, representing the antennæ. The antennæ are not so well-developed as in Myrmica (see Pl. VIII, Fig. 33). The fundaments of the antennæ were noted by Ganin ('69), but he did not know what they represented. He says: "Es muss hier noch bemerkt werden dass man in solchen Entwicklungs-stadium auf den Seitentheilen jedes Kopflappens ein besonders rundliches Hockerchen beobachten kann; übrigens existiren diese Hockerchen nur kurze Zeit und haben keine definitive Bedeutung; in den späteren Entwicklungsstadien kann man sie nicht mehr unterscheiden." Wheeler (I9Io, p. 72) mentions the presence of traces of the antennæ in the embryo of Formica gnava.

Back of the stomodæum occur three pairs of lobe-like evaginations, the fundaments of the mandibles, maxillæ, and labium respectively. On the three following segments occur three similar lobelike thickenings which are somewhat smaller than those representing the mouth parts. These represent the three pairs of thoracic legs. Back of the thoracic segments occur ten other segments, upon which occur very small paired tubercles representing abdominal appendages. On each side of the second thoracic segment occurs an irregular slit-like opening, the first thoracic spiracle. A pair of such openings occurs on the last thoracic segment and one on each of the following ten abdominal segments. Figure 23, Plate VI, represents a slightly older stage than Figure 22, Plate V. The dorsal part of the embryo has been removed, the yolk taken away, and the ventral part of the embryo straightened out to show all the segments. This corresponds to the stage of Formica gnava figured by Wheeler (I9Io, pp. 69). At this stage the ventral thickening extends almost halfway around to the dorsal side.

Figure 24 represents a later stage, in which the embryo has straightened, the mouth parts extending directly forward instead of ventral as in Figure 22. The mesenteron is smaller, and shows as a regular oval in the middle of the body. Its ends are in contact with the now more fully developed stomodæum and proctodæum, although communication between the two has not yet been established. The stomodxum extends backward as a narrow tube, while the proctodxum is a much shorter, somewhat oval sac.

The posterior border of the head is indicated by a constriction, but there is no differentiation between thorax and abdomen at this 
stage. The mouth parts are grouped nearer together and tend to bend in over the opening of the stomodæum. The two lobes representing the labium have grown together at their bases, making one plate. The small knobs representing the antennæ are still present, but are very inconspicuous. The papillæ representing the thoracic legs and the abdominal appendages have now disappeared.

The ganglia can be distinguished easily in faintly stained specimens at this stage. 'There is a double chain of ten abdominal ganglia, the last three of which are united in a compound ganglion in which the three constituent ganglia are easily distinguishable by their faintly-staining central portions. The double chain is continued in the thorax as three separate pairs of ganglia, the anterior one of which connects with the subœesophageal ganglion, which is easily seen to be made up of three united pairs of ganglia. The subœsophageal ganglion is connected with the supraœesophageal ganglion by a pair of commissures as usual.

Figure 25 represents an embryo at just about the time of hatching. It has practically the form of the young larva. The mesenteron has the same form as in the preceding stage except that its anterior end has narrowed considerably, giving it somewhat the appearance of the neck of a bottle. This neck is open at the anterior end, and encloses the posterior end of the stomodæum which is now open also, thus forming the valve-like connection between the stomodæum and the mesenteron. The proctodrum has changed considerably in shape. It has a middle portion which is wide and bladder-like, from the posterior end of which a narrow tube-like part leads back to the anus, and from the anterior end of which a short narrow part passes forward to end blindly against the posterior end of the mesenteron, the connection between these two divisions of the alimentary canal not yet having been formed.

The mouth parts are practically the same as in the larva, and the antennæ have disappeared. The nerve cord presents practically the same appearance as in the preceding stage except that the last three abdominal ganglia and the three parts of the subœsophageal ganglion are more closely united.

\section{THE, DEVELOPMENT OF THE EXTERNAL, FORM OF THE EMBRYO OF Myrmica scabrinodis Nyl.}

Since a colony of Myrmica scabrinodis var. sabuleti which I had in the laboratory was yielding an abundance of eggs while I was waiting for my Camponotus queen to begin laying, I decided to 
make a study of the development of the external form of the embryo of that species.

The eggs were killed and fixed in the same manner as has been described for the eggs of Camponotus. The eggs of Myrmica are much smaller than those of Camponotus, their greatest diameter being about $.45 \mathrm{~mm}$. and their shortest diameter being about $.35 \mathrm{~mm}$. They may be described as broadly ovate in form, with one end slightly smaller than the other. As in the eggs of Camponotus, there are two external membranes, the chorion and the vitelline membrane, the chorion being composed of twe layers-ectochorion and endochorion.

The appearance of the first differentiation of the germ band from the undifferentiated blastoderm may be described as follows. At the anterior pole occur two somewhat oval-shaped thickenings of the blastoderm lying side by side with a clear area between them. These thickenings are slightly raised above the surrounding blastoderm. The edges facing each other are nearly straight, sometimes concave, while the outer edges are convex. At the opposite pole is a more or less circular denser area surrounded by a clear ring. This clear ring is connected by a light streak with the clear space between the two thickenings at the anterior pole. On each side of this light streak, a slight thickening of the blastoderm indicates the beginning of the germ band. The two oval thickenings at the anterior pole are the procephalic lobes.

Figure 26, Plate VI, represents an early stage in which the embryo is curved around the yolk mass in the form of a capital C. There are slight indications of segmentation. The anterior end is thicker and wider than the posterior end, indicating the earlier development of the head region. The anterior and posterior ends are seen to be connected by the undifferentiated blastoderm.

Figure 27 , Plate VII, represents a later stage, in which the body segments are clearly indicated. The anterior and posterior ends, both of which are thickened, the anterior much more than the posterior, more closely approach each other, and the layer connecting the two ends has a large knob-like thickening near its middle. This thickening is composed of a large irregular mass of cells, and seems to be caused by a crowding and pushing outward of the cells of the layer connecting the two ends, as these ends approach each other. This laver continues at the sides, covering the yolk, and connects ventrally with the edges of the germ band. From a direct dorsal view this thickening is seen to be made up of two parts, separated laterally. This would naturally be the case if the thickening were caused in the way that has been suggested, that is, by the coming 
together of the anterior and posterior ends of the embryo and by the dorsal growth of the sides of the germ band.

The germ band has widened considerably, and now covers most of the ventral surface of the yolk. Figure 28 represents a view of the anterior end of the germ band at this stage, showing the procephalic lobes in front, the beginning of the evaginations representing the mandibles, maxillæ, and labium. At this stage there are only the faintest traces of the three pairs of thoracic appendages, and the invagination of the proctodæum has not yet begun.

In the stage represented by Figure 29, the curvature of the embryo is still greater, the anterior and posterior ends more closely approximating each other. The dorsal thickening between the anterior and posterior ends is present as before, and as a rule is somewhat larger than in the preceding stage. The segments are much more clearly differentiated, there being ten abdominal segments. The procephalic lobes have increased in size, and the lateral edges of the germ band have grown farther dorsally. The labrum is shown in Figure 30, which represents a dorso-frontal view of the same stage. Figure 30 shows also the extent of the invagination of the stomodrum and the lobe-like appendages representing the three pairs of mouth parts and the first two pairs of legs. Figure 3I, which represents a slightly different view of the same stage, shows also the last two pairs of thoracic appendages and the first pair of abdominal appendages, and on these segments also appear the first three pairs of spiracles. The invagination of the proctodeum is shown at the posterior end.

Figure 32, Plate VIII, represents a later stage, in which the labrum is well developed, pushing out in front of the invagination of the stomodxum, which has pushed farther inward. In fact, the posterior border of the labrum is continued inward to form the anterior wall of the invagination. 'The procephalic lobes are larger and the germ band has grown farther over the yolk. The proctodxum now appears as a distinct U-shaped thick-walled invagination. The dorsal thickening, made up of a cluster of cells, has disappeared in this stage. In stages just a little earlier than this, a constriction develops at the base of this thickening. This fact, together with the fact that in such stages the thickening is very easily broken away from its attachment as the embryo is moved about in the clearing agent, leads me to believe that it takes no part in the development of the embryo. The membrane covering the yolk, from which this cluster of cells is formed, is homologous with what we have called the amnion in Camponotus. This cluster of cells, then, seems to correspond with the so-called amniotic dorsal organ which Wheeler 
has described as occurring in Doryphora (Wheeler '89, pp. 356-358), but sections of the embryo at this stage do not show anything that would lead me to believe that it is absorbed into the yolk. The absence of such a structure in Camponotus illustrates one striking difference between the development in that genus and in Myrmica. In Camponotus the amnion becomes the dorsal body-wall.

At this age the segments are more deeply constricted off from each other. The three pairs of mouth parts are further developed, and the thoracic and abdominal appendages are present, although in a side view it is difficult to distinguish them from the body segments.

In the stage represented by Figure 33, the embryo is seen to be straightening somewhat, the posterior and anterior ends being farther apart. The segments are still more deeply constricted off from each other, and the lateral edges of the germ band have grown dorsad until they have almost completed the dorsal closure. The invagination of the stomodæum has grown farther inward, the posterior end of the stomodrum almost reaching the yolk. On the sides of the procephalic lohes appear the small tubercle-like thickenings which represent the antenna. The labrum and the three pairs of mouth parts more closely approximate each other and tend to bend in over the opening of the stomodæum. This is shown better in Figure 34, which represents a frontal view of the same stage.

In the stage represented by Figure 35, the embryo has straightened still more, and the dorsal closure has been completed. The mouth parts still more closely approximate each other and bend in over the stomodrum. The thoracic and abdominal appendages have disappeared, as have also the antennæ. The stomodæum and proctodrum extend inward as far as the yolk, which is now enclosed in the somewhat pear-shaped mesenteron. The ventral segments are constricted off into blocks, three pairs in the thorax and seven in the abdomen, the last three abdominal segments having united together. In each of these segments a primitive ganglion is evident, and in the last abdominal segment three ganglia appear, showing the compound nature of the segment. In the head region three separate ganglia can be distinguished, for the subœesophageal ganglion appears in the whole embryo to be all in one part.

Figure 36 represents a stage just before the egg hatches, when the embryo has practically the form of the young larva. The embryo has now bent completely over so that the flexure, instead of being on the dorsal side as before, is on the ventral side. The thoracic region has lengthened considerably. The mouth parts are in their normal position for the larva and have practically the same form. 
The stomodæum is discernible as a long narrow tube leading back to the mesenteron and connecting with it at about the level of the third thoracic segment. The connection is of the same valve-like character as has been described for the similar stage in the embryo of Camponotus. The proctodæum also is similar to that described for the corresponding stage of Camponotus. There is a wide middle part connected at one end by a short, narrow, tube-like part with the anus and similarly, at the other end, with the posterior end of the mesenteron. The connection between the proctodæum and the mesenteron has not yet been established. The segmentation is essentially as in the preceding stage; the last three abdominal ganglia and the three ganglia composing the subøesophageal ganglion are more closely united, however, and the supraœsophageal ganglion is larger than in the preceding stage. 


\section{LITERATURE CITED}

Bethe, A.

I902. Die Heimkehrfähigkeit der Ameisen und Bienen zum Teil nach neuen Versuchen. Biol. Centralb., Vol. 22, pp. I932 I $5,234-238$.

Blochmann, F.

I884. Ueber eine Metamorphose der Kerne in den Ovarialeiern und über den Beginn der Blastodermbildung bei den Ameisen. Verhand. naturh.-med. Vereins Heidelberg, N. F., Bd. 3, pp. $243-247$.

I892. Über das Vorkomen von bakterienähnlichen Gebilden in Geweben und Eiern Verschiedener Insekten. Centralbl. f. Bakteriol. u. Parasitenk, Bd. I I, p. 234.

Bütschli, O.

I870. Zur Entwicklungsgeschichte der Biene. Zeitschr. f. Wiss. Zool., Bd. 20.

Carrière, Justus.

I897. Die Entwicklungsgeschichte der Mauerbiene (Chalicodoma muraria, Fabr.) im ei hrsg. von Otto Bürger. Halle.

Fielde, A. M.

I90I. Further study of an ant. Proc. Acad. Nat. Sei. Phila., Vol. 53, pp. 425-429.

I904. Portable ant-nests. Biol. Bull., Vol. 7, pp. 2I 5-220.

I905. Observations on the progeny of virgin ants. Biol. Bull., Vol. 9, pp. 355-360.

Forbes, S. A.

I89I. Bacteria normal to digestive organs of Hemiptera. Bull.

I11. State Lab. Nat. Hist., Vol. 4, pp. I-7.

1908. Habits and behavior of the corn-field ant, Lasius niger var. americamus. Bull. Ill. Agr. Exper. Sta., No. I3I; also in 25th Rep. State Ent. I11., pp. 27-40.

Ganin, M.

I869. Über die Embryonalhülle der Hymenopteren- und Lepidopteren-Embryonen. Mémoirs de L’Académie Impériale des

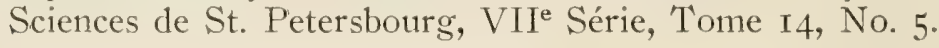

Graber, V.

I888. Vergleichende Studien über die Kiemhüllen und die Rück enbildung der Insecten. Denkschr. Acad. Wiss. Wien., Bd. 55 , Pp. IO9-I 58 . 
Korschelt and Heider.

I899. Textbook of embryology of the invertebrates.

Mercier, L.

1907. Recherches sur les bactéroides des Blattides. Archiv. für Protistenkunde, Bd. 9, pp. 346-356.

Tanquary, M. C.

I9II. Experiments on the adoption of Lasius, Formica, and Polyergus queens by colonies of alien species. Biol. Bull., Vol. 20, No. 5, Apr., I9I I, pp, 28I-308.

Wheeler, W. M.

I889. The embryology of Blatta germanica and Doryphora decemlineata. Journal of Morphology, Vol. 3, pp. 29I-386. I903. The origin of female and worker ants from the eggs of parthenogenetic workers. Science, N. S., Vol. I8, pp. 830833 .

I906. On the founding of colonies of queen ants, with special reference to the parasitic and slave-making species. Bull. Am. Mus. Nat. Hist., Vol. 22, Art. 4, pp. 33-IO5. I9ro. Ants, their structure, development, and behavior. 


\section{EXPLANATION OF PLATES}

\section{Abrreviations}

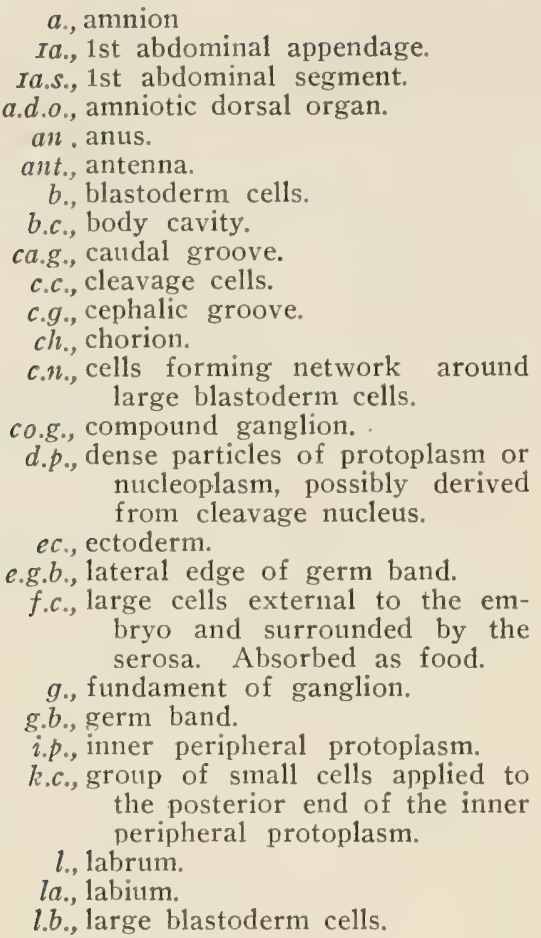

l.c., large polynucleate cells of the blastoderm.

l.g., lateral groove.

m., mandible.

me., mesoderm.

mes., mesenteron.

mo., mouth.

m.x., maxilla.

m.p., middle plate.

$n$, cleavage nucleus.

nu., nuclei of the cells.

p., proctodrum.

p.l., procephalic lobes.

$p . n$, protoplasmic network.

p.p., peripheral protoplasm.

$r . n$, remains of large nucleus.

s., serosa.

s.c., scattered cells of the body cavity.

$s p .$, spiracle.

st., stomodxum.

su., supraœsophageal ganglion.

$s u b$. subosophageal ganglion.

$t$., thickenings of the inner layer of peripheral protoplasm.

$I t ., 1$ st thoracic appendage.

It.s., 1st thoracic segment.

\%, vacnole

v.m., vitelline membrane.

y., yolk mass.

y.c., so-called yolk cells.

y.g., yolk granules.

\section{Plate I}

FiG. 1. Longitudinal section through the egg of Camponotus 1 hour old. $\times 52$.

FIG. 2. Large nucleus found in posterior end of egg of Camponotus 1 hour old. $\times 360$.

Fig. 3. Small nucleus found in posterior end of egg of Camponotus 1 hour old. $\times 405$.

FIG. 4. Longitudinal section through egg of Camponotus 20 hours old, chorion removed. $\times 52$.

FIG. 5. Longitudinal section through egg of Camponotus 1 day old. $\times 52$.

\section{Plate II}

FIG. 6. Longitudinal section through egg of Camponotus a little older than the stage represented by Fig. $5 . \times 52$.

FIG. 7. Portion of a section taken through the layer of peripheral protoplasm of anterior end of egg of Camponotus. Same age as that represented by Fig. $6 . \times 405$.

FIG. 8. Longitudinal section through egg of Camponotus 30 hours old. $\times 52$. 


\section{Plate III}

Fig. 9. Longitudinal section through egg of Camponotus 2 days old. $\times 52$.

FIG. 10. Transverse section through blastoderm near posterior end of germ band. Same age as the one represented by Fig. $9 . \times 78$.

FIG. 11. Transverse section through same stage as that represented by Figs. 9 and 10. Taken near anterior end of germ band. $\times 78$.

FIG. 12. Longitudinal section through blastoderm of Camponotus at a somewhat later stage than that represented by Fig. $9 . \times 52$.

\section{Plate IV}

FIG. 13. Transverse section through anterior end of blastoderm of Camponotus. Same age as that represented by Fig. 12. $\times 78$,

Fig. 14. Transverse section through middle of blastoderm. Same age as that represented by Fig. 12 . $\times 78$.

Fig. 15. Longitudinal section through blastoderm of Camponotus 5 days old. $\times 52$.

FIG. 16. Longitudinal section through blastoderm of Camponotus 6 days old. $\times 78$.

FIG. 17. Longitudinal section through blastoderm of Camponotus 8 days old. $\times 52$.

\section{Plate, V}

FIG. 18. Transverse section through blastoderm of Camponotus 8 days old. $\times 105$.

FIG. 19. Transverse section through embryo of Camponotus 14 days old. $\times 105$.

FIG. 20. Transverse section through embryo of Camponotus 15-20 days old. $\times 105$.

FIG. 21. Embryo of Camponotus 8-12 days old. $\times 52$.

FIG. 22. Embryo of Camponotus showing development of appendages. $X 52$.

\section{Plate VI}

Fig. 23. Ventral view of germ band of the same age as that represented by Fig. 22. The yolk mass has been removed and the embryo, which is normally curved over the yolk, has been straightened out. $\times 5 \%$.

Fic. 24. Embryo of Camponotus. A later stage than that represented by Fig. 23. $\times 52$.

FIG. 25. Embryo of Camponotus at a stage just before hatching. $\times 31$.

Fig. 26. Embryo of Myrmica. Early stage. $\times 91$.

\section{Plate VII}

FIG. 27. Embryo of Myrmica, at a stage somewhat later than that represented by Fig. 26. X 114

Fig. 28. Ventral view of anterior end of germ band of same age as that represented by Fig. $27 . \times 91$.

FIG. 29. Side view of later stage of embryo of Myrmica than that shown in Fig. $27 . \times 91$.

FIG. 30. Ventral view of same stage as the embryo shown in Fig. $29 . \times 91$.

FIG. 31. A slightly different view of the same embryo. $\times 91$.

\section{Pi.ATE VIII}

Fig. 32. A later stage of the embryo of Myrmica. $\times 91$.

FIG. 33. A still later stage of the embryo of Myrmica. $\times 91$.

Fif. 34. Ventro-frontal view of same embryo as in Fig. $33 . \times 91$.

Fig. 35. Embryo of Myrmica at a stage when it is straightening. $X 80$.

Fig. 36. Embryo of Myrmica just before hatching. $\times 91$. 

PLATE I


FIG. 3

FIG. 2

FIG. 1



FIs. 4



FIG. 5 



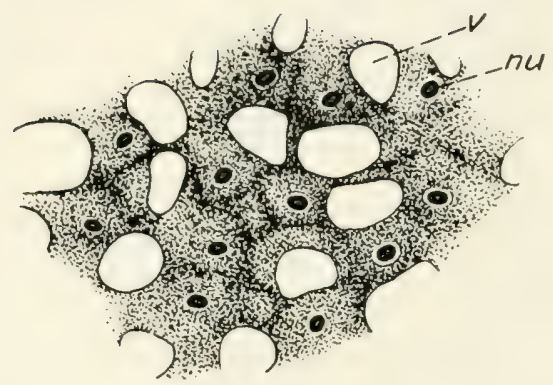

FIG. 7

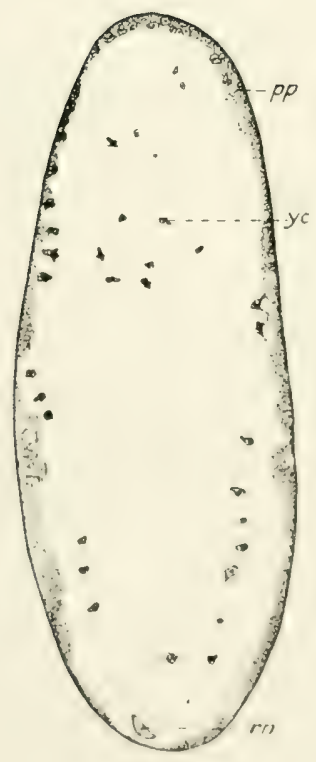

FI(ะ. 6

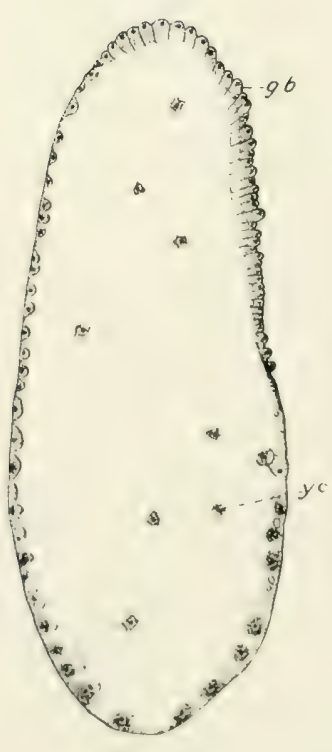

FI): 8 

Plate III
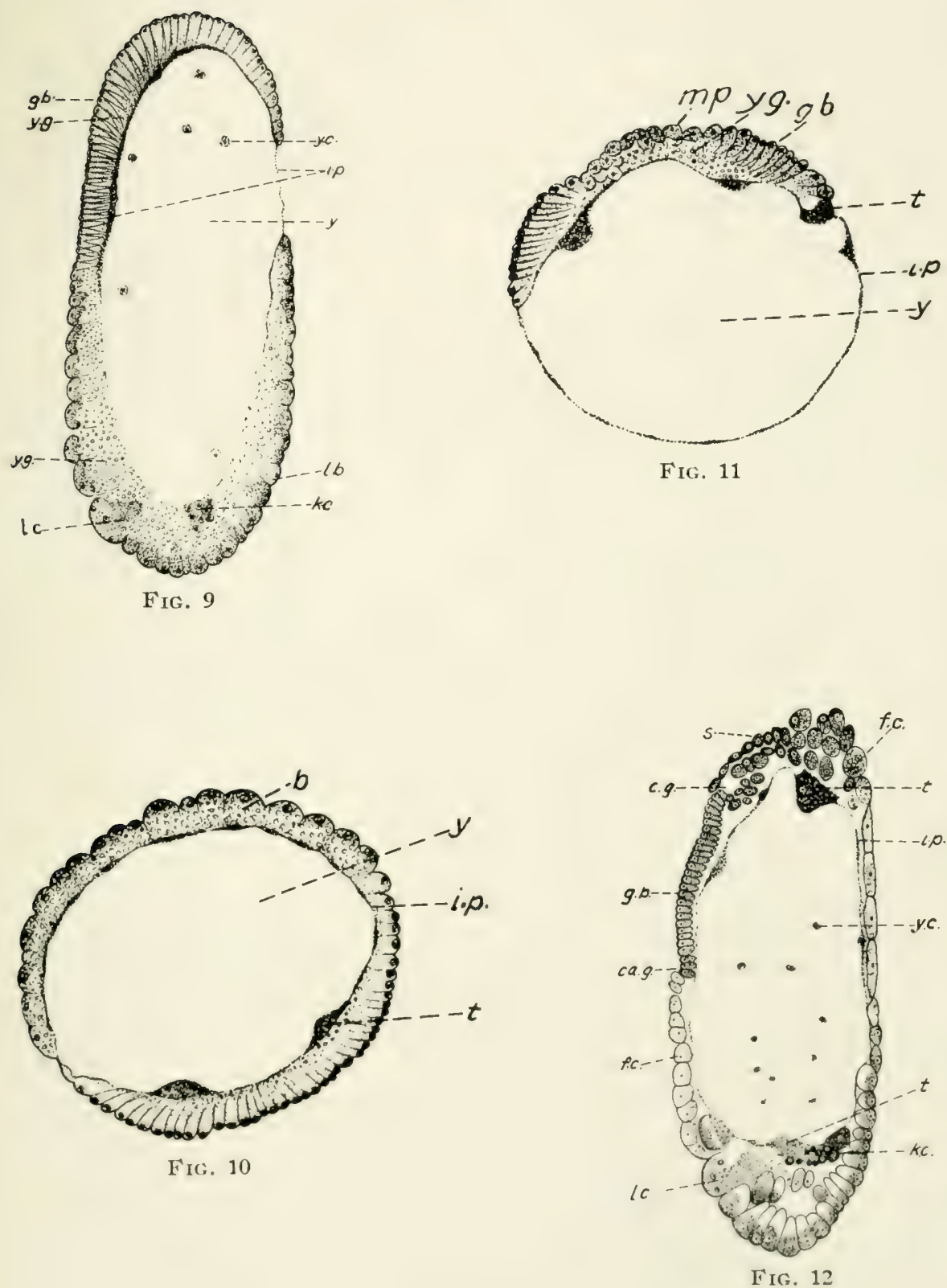



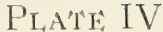

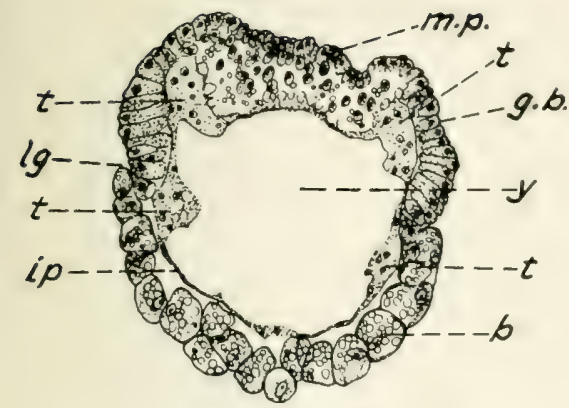

FIG. 13
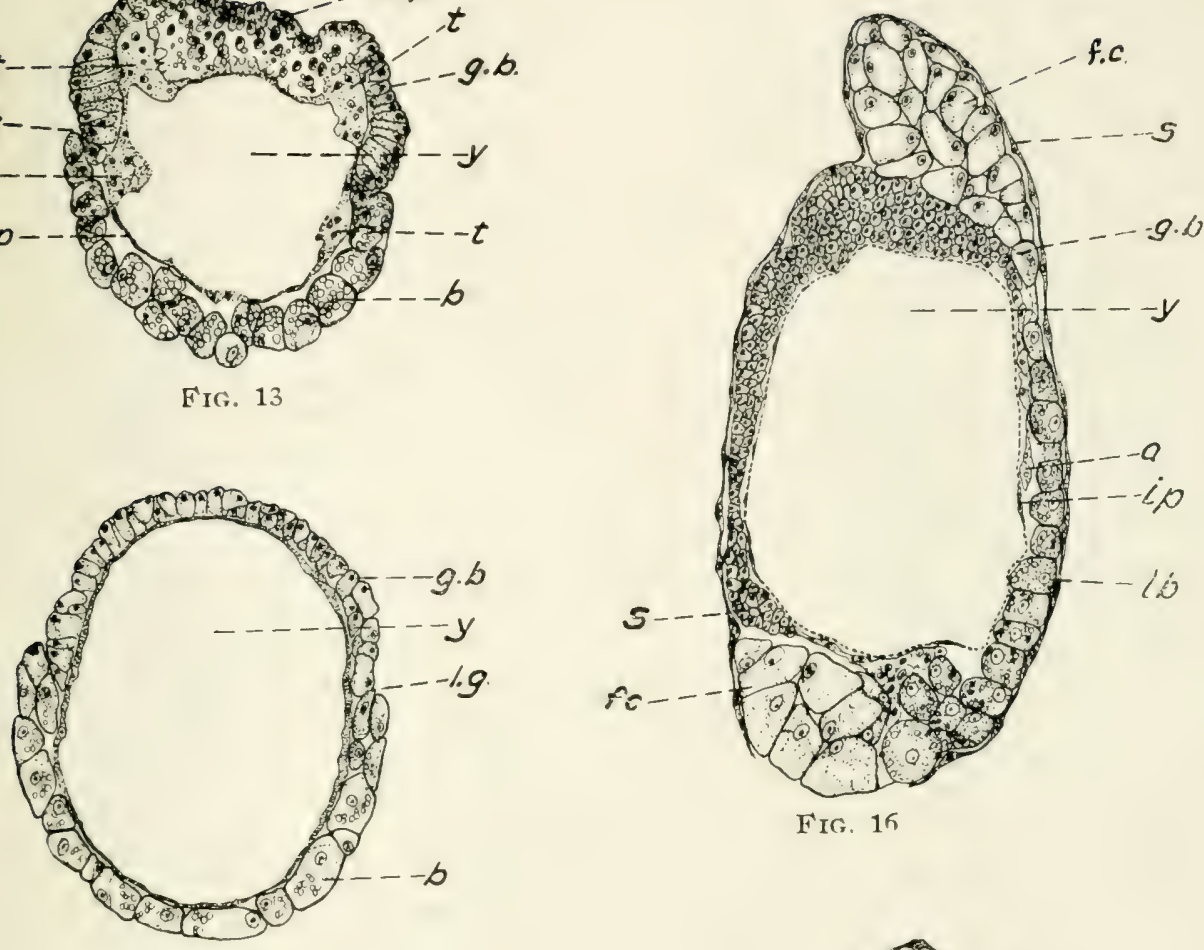

FIG. 14

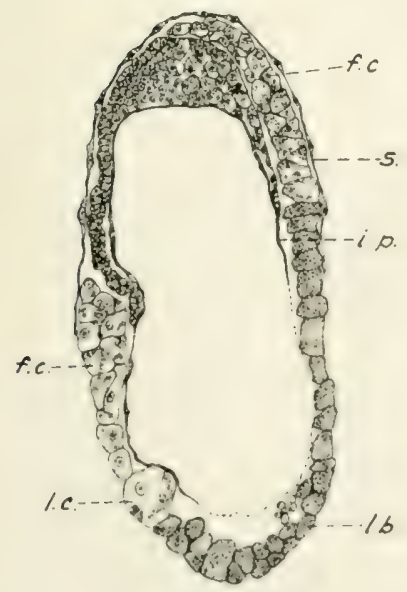

Frg. 15

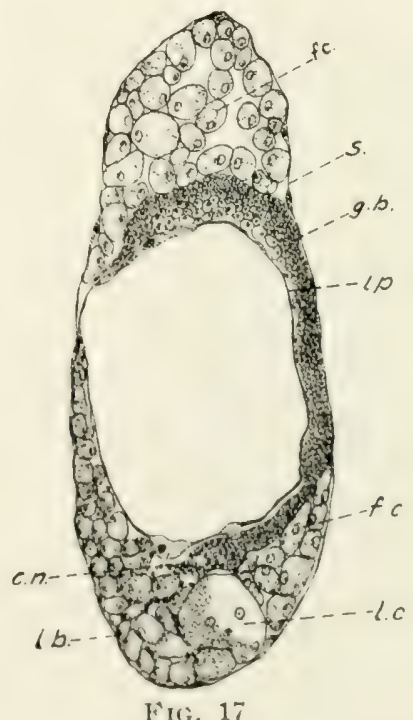



Plate
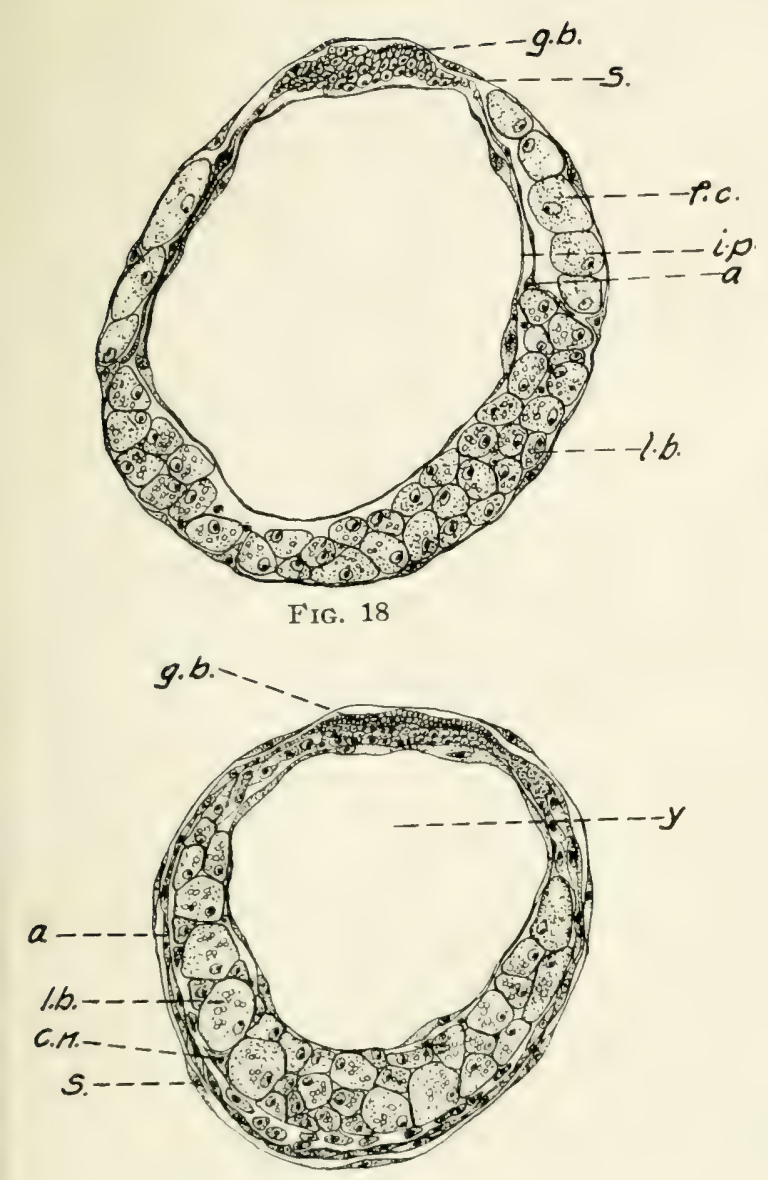

FIG. 19
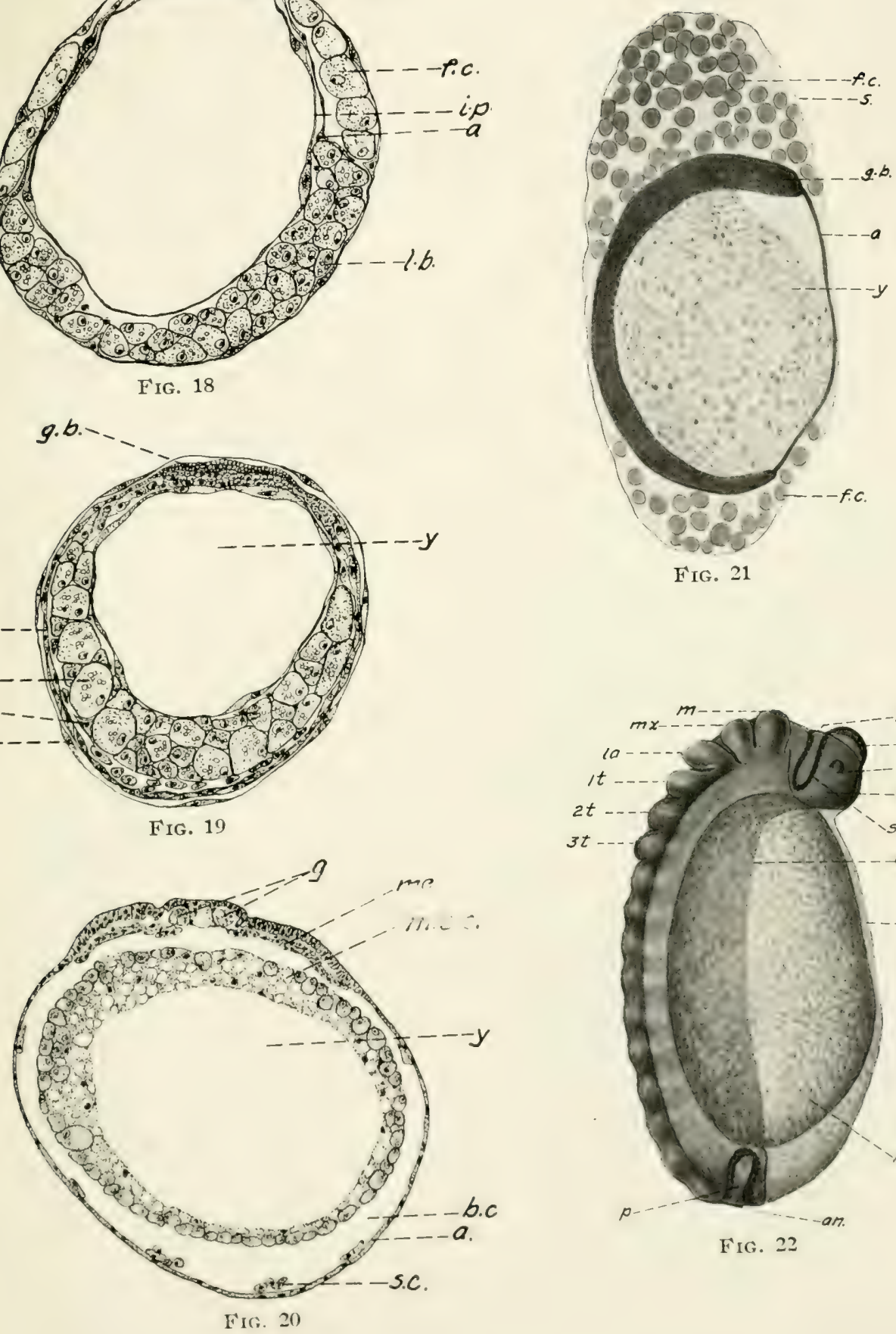

F IG. 21

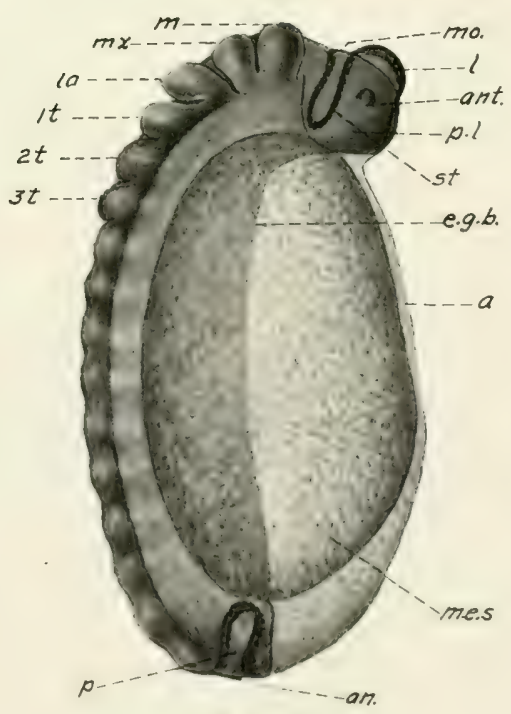

Fig. 22 



$$
0
$$





\section{Plate VII}



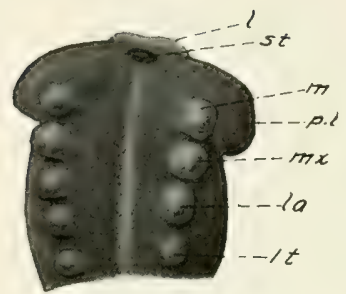

FIG. 30

FIG. 27

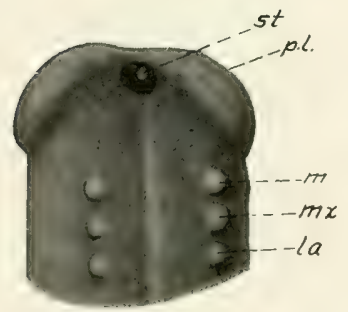

FIG. 28

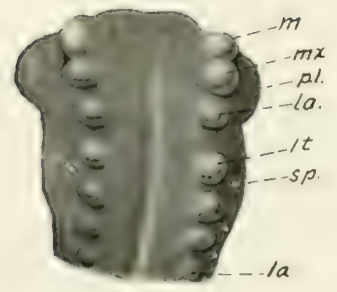

Fig. 31

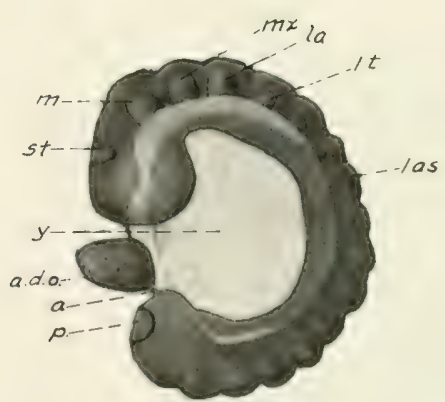

Fig. 29 



$$
\begin{aligned}
& 5 \\
& 0 \%
\end{aligned}
$$





